\title{
Surviving the Holocaust: A Meta-Analysis of the Long-Term Sequelae of a Genocide
}

\author{
Efrat Barel \\ University of Haifa and the Max Stern Academic \\ College of Emek Yezreel
}

\author{
Marinus H. Van IJzendoorn \\ Leiden University
}

\author{
Marian J. Bakermans-Kranenburg \\ Leiden University
}

\author{
Abraham Sagi-Schwartz \\ University of Haifa
}

\begin{abstract}
The current set of meta-analyses elucidates the long-term psychiatric, psychosocial, and physical consequences of the Holocaust for survivors. In 71 samples with 12,746 participants Holocaust survivors were compared with their counterparts (with no Holocaust background) on physical health, psychological wellbeing, posttraumatic stress symptoms, psychopathological symptomatology, cognitive functioning, and stressrelated physiology. Holocaust survivors were less well adjusted, as apparent from studies on nonselected samples (trimmed combined effect size $d=0.22,95 \%$ CI $[0.13,0.31], N=9,803$ ) and from studies on selected samples $(d=0.45,95 \% \mathrm{CI}[0.32,0.59], N=2,943)$. In particular, they showed substantially more posttraumatic stress symptoms (nonselect studies: $d=0.72,95 \%$ CI $[0.46,0.98], N=1,763$ ). They did not lag, however, much behind their comparisons in several other domains of functioning (i.e., physical health, stress-related physical measures, and cognitive functioning) and showed remarkable resilience. The coexistence of stress-related symptoms and good adaptation in some other areas of functioning may be explained by the unique characteristics of the symptoms of Holocaust survivors, who combine resilience with the use of defensive mechanisms. In most domains of functioning no differences were found between Israeli samples and samples from other countries. The exception was psychological well-being: For this domain it was found that living in Israel rather than elsewhere can serve as a protective factor. A biopsychological stress-diathesis model is used to interpret the findings, and future directions for research and social policy are discussed.
\end{abstract}

Keywords: Holocaust, survivors, meta-analysis, traumatization, resilience

Six decades after the end of World War II, clinicians and researchers are still divided regarding the long-term effects of the Holocaust on survivors. The central question of the current study is whether differences exist in the physical and psychological

Efrat Barel, Center for the Study of Child Development, University of Haifa, Haifa, Israel, and Department of Health Systems Administration, the Max Stern Academic College of Emek Yezreel, Yezreel Valley, Israel; Marinus H. Van IJzendoorn and Marian J. Bakermans-Kranenburg, Centre for Child and Family Studies, Leiden University, Leiden, the Netherlands; Abraham Sagi-Schwartz, Center for the Study of Child Development, University of Haifa.

Marinus H. Van IJzendoorn and Marian J. Bakermans-Kranenburg were supported by awards from the Netherlands Organization for Scientific Research (NWO Spinoza Prize and Vidi Grant 452-04-306, respectively). The initial phase of this work was carried out by Abraham Sagi-Schwartz during his residence as a Jennings Randolph Senior Fellow at the United States Institute of Peace. The generous support of the United States Institute of Peace is deeply appreciated. We sincerely thank Hadas Wiseman for her valuable contribution in the various stages of the research process.

Correspondence concerning this article should be addressed to Marinus H. Van IJzendoorn, Centre for Child and Family Studies, Leiden University, P.O. Box 9555, NL-2300RB Leiden, the Netherlands, or to Abraham Sagi-Schwartz, Center for the Study of Child Development, University of Haifa, 6035 Rabin Building, Haifa 31905, Israel. E-mail: vanijzen@ fsw.leidenuniv.nl or sagi@psy.haifa.ac.il health of Holocaust survivors as compared to those who did not experience the Holocaust. The Holocaust was one of the most traumatic catastrophes ever designed by man, with humans beings exposed to horrifying atrocities. Holocaust survivors provide an opportunity for studying the enduring effects of massive trauma and extremely stressful experiences (Carmil \& Breznitz, 1991). Insights that can be gained from the current study concerning the long-term consequences of the Holocaust on survivors may extend to adaptational challenges for survivors of other, more recent genocides, each characterized by distinctive features. Furthermore, in light of the renewed interest in understanding Holocaust survivors' needs in the political arena and public debate (e.g., financial compensation, rehabilitation for the handicapped, special accommodations) and the rise of diverging opinions as to the legitimacy of such compensations, studying the long-term consequences of the Holocaust is of critical importance.

\section{The Holocaust Experience}

The 20th century witnessed radical changes in the world: industrial, technological, sociological, and political turmoil; two world wars; and the success (albeit temporary) of aggressive totalitarian regimes (de Vries, Suedfeld, Krell, Blando, \& Southard, 2005). The Holocaust refers to the massive destruction of European Jewry during World War II, when millions were systematically persecuted and exterminated solely because of their social, cultural, 
ethnic, or religious characteristics. The atrocities of the Nazis against Jews and other minority populations during the war were horrific. Victims were rounded up and transported like animals to concentration camps, where they endured continuous threats to life, depersonalization, and loss of significant others. They suffered from horrendous living and working conditions, starvation, and diseases, and those who survived were subjected to atrocious experiences (Eitinger \& Major, 1993; Mazor, Gampel, Enright, \& Orenstein, 1990). Other persecuted Jews were living in hiding under false identities in constant stress of discovery; some often spent months in primitive and inhuman conditions or fighting alongside the partisans (Ben-Zur \& Zimmerman, 2005; Yehuda, Schmeidler, Siever, Binder-Brynes, \& Elkin, 1997).

The traumatic experiences of Holocaust survivors provide the ground for in-depth studies of the long-term consequences of trauma on later adaptation and adjustment. The importance of studying the long-term effects of the Holocaust on survivors produced an extended body of literature (e.g., Krell \& Sherman, 1997). But six decades after the end of World War II clinicians and researchers are still divided about such effects of the Holocaust. Do most survivors continue to suffer from psychopathological disorders, such as chronic anxiety or depression (Niederland, 1968) and personality impairment (e.g., Kohn Dor-Shav, 1978)? Or is this continuing psychological impairment restricted to a small, nonrepresentative portion of survivors, and do most of them have productive and successful lives despite the atrocities they endured (e.g., Leon, Butcher, Kleinman, Goldberg, \& Almagor, 1981)?

\section{Psychological Consequences for Holocaust Survivors}

The long-term effects of the Holocaust on survivors can be examined with a focus on dysfunctions - as is often the case- but also with a focus on posttrauma psychological strength and growth (Cassel \& Suedfeld, 2006). A review of the research and clinical literature reveals that in the 1950s and early 1960s reports of the psychological impact of the Holocaust were presented mainly by psychiatrists who treated survivors as patients or by eyewitness accounts of the survivors themselves (Frankl, 1962; Krystal, 1968; Niederland, 1968). These reports focused directly on the survivors and the atrocities they suffered. After a period of silence, in the 1970s the focus shifted to long-term psychopathological effects (Lomranz, 1995). Subsequently, in the 1980s, the Holocaust was featured as part of a posttraumatic stress syndrome framework (Kahana et al., 1997). In the last two decades, the literature has shown more optimistic findings, though still suggesting a divergent picture. Some reports pointed to the negative effects of the Holocaust on survivors (e.g., Kahana, Harel, \& Kahana, 1988), but others focused on survivors' resilience (e.g., Cassel \& Suedfeld, 2006).

\section{Maladaptive Consequences}

After World War II, mental health professionals coined the term survivor syndrome (Niederland, 1968) or concentration camp syndrome (Eitinger, 1964) to define the psychopathology that characterized Holocaust survivors (Krystal, 1968). This syndrome consists of a combination of a chronic sense of anxiety (De Graaf, 1975) and depression (Niederland, 1968), feelings of guilt (Chod- off, 1986), emotional disruption, cognitive disturbances (especially regarding memory and concentration), and personality problems (Prager \& Solomon, 1995).

Survivor syndrome symptoms closely resemble those currently identified as posttraumatic stress disorder (PTSD). The term PTSD was introduced into diagnostic nomenclature in 1980 and was adopted by the Diagnostic and Statistical Manual of Mental Disorders (DSM; 3rd ed.; American Psychiatric Association, 1980). Further editions of the DSM revised the original conceptualization of PTSD by referring to victims of trauma exposed to combat and natural disasters or to other threats to personal, physical, and psychological well-being. Characteristics of the disorder listed in the DSM (4th ed., text rev.) include the following: (a) reexperiencing the traumatic event (e.g., intrusive thoughts); (b) avoidance of stimuli associated with the traumatic event and numbing or feelings of detachment; and (c) a variety of autonomic and behavioral indicators of overarousal, including hyperalertness and other signs of sympathetic arousal (American Psychiatric Association, 2000).

A large body of research supports the conceptualization of the survivor syndrome, the concentration camp syndrome, PTSD, and similar psychopathological symptomatology as characteristic of the consequences of the Holocaust. Initial studies on Holocaust survivors showed that most of them reported problems such as nervousness, irritability, memory impairment, dysphoric mood, emotional instability, sleep impairment, anxiety, loss of initiative, and somatic complaints (Chodoff, 1963; Helweg-Larsen et al., 1952). Other findings showed that many survivors also experienced a state of unresolved mourning. The loss of loved ones generated intense feelings of sadness, helplessness, and rage, alongside feelings of survival guilt (Kapeliuk, 1995; Sagi, Van IJzendoorn, Joels, \& Scharf, 2002; Sagi-Schwartz et al., 2003). Studies examining the frequency of PTSD and other psychiatric symptoms in Holocaust survivors showed that survivors had more symptoms than did comparison groups (Breslau, 2002; M. Cohen, Brom, \& Dasberg, 2001; Landau \& Litwin, 2000). These symptoms included depression, anxiety, somatization, and angerhostility; lower physical, psychological, and social quality of life (Amir \& Lev-Wiesel, 2003); and more sleep disturbances, nightmares, nervousness, intrusive thoughts, headaches, and exhaustion (Joffe, Brodaty, Luscombe, \& Ehrlich, 2003).

Other studies examined additional domains of functioning, such as emotional distress and psychological well-being. Levav and Abramson (1984), for example, studied the long-term effects of concentration camp experiences on emotional distress. They compared 380 concentration camp survivors with a European-born comparison group that had not been interned in camps, finding that the former showed more emotional distress. Carmil and Carel (1986) conducted a large study on emotional distress, general life satisfaction, and psychosomatic complaints in a sample of Holocaust survivors and a comparison group. They did not find differences between the groups on general life satisfaction and psychosomatic complaints, but they did find differences in emotional distress, with Holocaust survivors presenting more complaints (e.g., frequent anxiety, irrational fears, uncontrolled anger) than the comparison group. Nadler and Ben-Shushan (1989) focused on a host of outcomes, including psychological well-being of Holocaust survivors. Their findings suggest that the effects of the Holocaust were still evident four decades later. Holocaust survi- 
vors rated themselves as less emotionally stable, with lower feelings of self-control, dominance, and assertiveness and lower levels of energy. They appeared to have more difficulties in emotional expression and felt worthless and inadequate more often than did their comparisons.

\section{Normative or Adaptive Consequences}

In conjunction with reports on the adverse effects of exposure to the Holocaust, studies demonstrating no differences between Holocaust survivors and comparison participants have emerged in the last two decades. Psychological growth and success of survivors have sometimes been documented. Extreme torment does not necessarily result in disorder, and some individuals who underwent extreme trauma seem to be well adjusted (Lomranz, 1995). Several studies have provided support for resilience in survivors of trauma, genocide, and persecution (e.g., Ferren, 1999; Rousseau, Drapeau, \& Rahimi, 2003).

The themes of human adaptation and adjustment have been central to theories focusing on personality, social behavior, and mental health (Lazarus \& Folkman, 1984). Behavioral and social scientists have been intrigued by the human capacity to endure and even flourish under extreme stress (Harel, Kahana, \& Kahana, 1988). The voices of adjustment and adaptation have been heard in the realm of the Holocaust as well. Eitinger and Major (1993) maintained, for example, that the findings of pathology in Holocaust survivors were misinterpreted, in particular the assertion that pathological reactions would persist and become unchangeable. They argued instead that human adaptability and the "regenerative powers of the ego" had been overlooked (Eitinger \& Major, 1993, p. 628). Many survivors appear to have integrated into their new adopting societies, becoming actively and successfully involved with their family and community.

Some empirical studies focusing on the adaptive capacities of Holocaust survivors reveal minimal differences, if any, when compared to those of non-Holocaust comparison groups. These findings highlight the satisfaction that survivors draw from their family and work, the development of successful and stable professional careers, and their enjoyment of social interactions (Lomranz, 1995). Survivors' involvement in social activities and achievements on a wide spectrum of indices of social functioning may be similar to those of comparison participants (Joffe et al., 2003). For some aspects of adaptation, survivors did even better than non-Holocaust comparison groups (Harel et al., 1988; Leon et al., 1981), demonstrating resilience and strength in overcoming new adversities (Shanan \& Shahar, 1983). Robinson et al. (1994), for example, examined the reaction of Holocaust survivors to new threat and trauma, namely the Gulf War and the SCUD missile attack on Israel, including the threat that missiles potentially carried chemical or biological weapons (which did not materialize). These investigators did not find differences between the reaction to the Gulf War by Holocaust survivors and the comparison group. Some of the survivors even expressed feelings of immunity and hardiness fueled by their Holocaust experiences. Other intriguing findings reveal that Holocaust survivors, more than members of comparison groups, believe that there is justice in the world, that mankind is in control, and that the world is a good place (M. Cohen et al., 2001). Furthermore, in other investigations they have hope for a better future (Carmil \& Breznitz, 1991), and they score higher on measures of self-esteem and sense of coherence (Cassel \& Suedfeld, 2006).

A number of explanations can be entertained for these findings of resilience in Holocaust survivors. In a meta-analytic study of families of Holocaust survivors examining intergenerational transmission of Holocaust-related traumatic experiences from survivors to their offspring, no secondary traumatization effects were found (Van IJzendoorn, Bakermans-Kranenburg, \& Sagi-Schwartz, 2003). Secondary traumatization refers to effects of events that did not take place in the lives of the second-generation participants themselves but in those of their parents, who may or may not have communicated their experiences in a verbal or nonverbal way. Van IJzendoorn et al. referred to Paris' (2000) biopsychological stressdiathesis model of PTSD as an explanatory paradigm, with a focus on prewar (positive) experiences of survivors with their families as a protective factor. In other words, survivors may have established secure relationships with their attachment figures, which in turn served as a buffer against the later atrocities they have endured, enabling their proper functioning after the Holocaust. An alternate explanation refers to the possible presence of a genetic predisposition for PTSD, whereby survivors may have been protected against PTSD through genetically transmitted characteristics. Finally, it was suggested that existing social support networks may serve as a protective factor (Van IJzendoorn et al., 2003).

\section{Possible Explanations for the Inconsistent Findings}

This nonexhaustive review of the literature clearly shows that the perspective on long-term effects of the Holocaust on survivors is equivocal. Some studies have concluded that Holocaust survivors demonstrate psychological and psychiatric disturbances, whereas others suggest that Holocaust survivors function well both in terms of psychological well-being and of interpersonal functioning. A number of theoretical and methodological issues may contribute to the observed differences among the studies.

First, many of the Holocaust studies follow a psychodynamic framework that holds that severe adversity in childhood inevitably leads to lasting negative consequences (Harel, 1995; Sigal, 1995). At the same time studies rooted in nonpsychodynamic approaches are guided by research questions that explore the adaptation efforts, adjustment, and well-being of the survivors, with less focus on psychopathological outcomes (Harel et al., 1988; Lomranz, 1995). Thus, different research questions and paradigms may lead to different methods and outcomes.

Second, there is much diversity between the studies with respect to key methodological features, including selection of the target population and nature of sampling. A challenge in Holocaust studies is sampling the target population. The criteria for defining Holocaust survivors vary. Some studies have focused on survivors of concentration camps apart from other survivors (e.g., Antonovsky, Maoz, Dowty, \& Wijsenbeek, 1971; Levav \& Abramson, 1984; Nadler \& Ben-Shushan, 1989), whereas other studies have investigated survivors as one undifferentiated group (e.g., Amir \& Lev-Wiesel, 2003; M. Cohen et al., 2001). Another decision is whether to recruit clinical or nonclinical samples. Some of the studies on Holocaust survivors involved participants evaluated for the purpose of obtaining reparations from the German government (Chodoff, 1963). Other studies examined survivors who sought medical or mental health/therapeutic help (Niederland, 
1968). Nonclinical studies involved survivors in the community who did not seek professional help, and they were therefore likely to involve participants from more diverse survivor populations (e.g., Harel et al., 1988). There is evidence that Holocaust survivors from clinical samples perform worse on various outcome measures than do comparison groups, including clinical samples of individuals who did not live through the Holocaust (e.g., E. Cohen, Dekel, Solomon, \& Lavie, 2003; Peretz, Baider, Ever-Hadani, \& Kaplan De-Nour, 1994; Yehuda, Kahana, Southwick, \& Giller, 1994).

Two main sampling methods have been used to recruit survivors. In the first method, large populations that include Holocaust survivors are surveyed or participants are drawn from the entire population of Jewish households that reside in a given area (e.g., Eaton, Sigal, \& Weinfeld, 1982). The essential characteristic of this approach is the nonselect nature of the sampling. It does not target Holocaust survivors as a group; instead, it recruits participants from a larger community that is not inherently associated with Holocaust survivors but consists of survivors and nonsurvivors (see below). The second method employs convenience sampling and is thus a select method, on the basis either of the snowball method of personal referral or of lists of names obtained from survivors' organizations and gatherings (Shmotkin \& Lomranz, 1998; see Van IJzendoorn et al., 2003, for a meta-analytic study of effects of the Holocaust on survivors' offspring using this design feature as moderator).

A basic methodological requirement for strengthening the internal validity of the research design is the inclusions of a nonHolocaust comparison group. Defining the comparison group is not trivial. Some studies compared Holocaust survivors with European-born Jews who immigrated to America or to Israel before the war (e.g., Carmil \& Breznitz, 1991; Carmil \& Carel, 1986; Eaton et al., 1982). Other studies included respondents regardless of whether or not they had emigrated from Europe (e.g., Ben-Zur \& Zimmerman, 2005).

Country of residence after the Holocaust may also affect survivors' adaptation and thus explain variation in study outcomes. The challenges imposed on Holocaust survivors who immigrated to Israel, Australia, United States, or Canada were in some respects alike. All immigrants had to adjust to new surroundings, learn new languages, and build new lives (Eitinger \& Major, 1993). The communities absorbing the survivors were, in all likelihood, unable to fully understand and respond to the atrocities they had experienced (Prager \& Solomon, 1995). Despite the common challenges of immigration, several studies have stressed the centrality of the cultural dimension. Van IJzendoorn et al. (2003) suggested that living in Israel may serve as a protective mechanism, because survivors residing there may have found more meaning in the common goal of building a new society and perhaps felt safer from anti-Semitism in a predominantly Jewish community. Others have suggested that living in Israel was a risk for the psychological well-being of the survivors (Kahana et al., 1988). That is, upon arriving in Israel the survivors were expected by the local community to be silent about their suffering (Segev, 1992), because all efforts were geared to the building of the new nation. Lack of opportunity to convey suffering and pain might thus be a risk factor to mental health. Also, because life in Israel is one of perpetual danger owing to political instability in the
Middle East, the continuing threat to survival may affect Holocaust survivors, who are vulnerable to additional stressors.

Sex has been more often addressed in research on psychopathology. It appears that women are more prone than men to develop PTSD and other mental disorders following exposure to traumatic events (Brave Heart, 1999; Breslau, Davis, Andreski, \& Peterson, 1991; Freedman et al., 2002). But findings among Holocaust survivors are inconsistent in this regard (Collins, Burazeri, Gofin, \& Kark, 2004). A detailed examination of the different domains of functioning shows diverging results. Landau and Litwin (2000) suggested that PTSD symptoms may be a legitimate outlet for men to express distress. According to this view, men are expected to demonstrate more posttraumatic stress symptoms than are women. But studies focusing on other psychopathological symptomatology suggest that women display more psychiatric symptoms than men (e.g., Carmil \& Carel, 1986; Collins et al., 2004; Eaton et al., 1982).

There are also conflicting findings regarding psychological well-being and physical health. Some studies have suggested that because the experience of total helplessness was particularly inconsistent with the male self-image, men were more adversely affected than women by the Holocaust experience (Danieli, 1982). There is also evidence, however, for the contrasting hypothesis that women were more affected than men by their exposure to the traumatic events (Carmil \& Carel, 1986), as well as for the absence of any difference (e.g., Landau \& Litwin, 2000). Poorer physical health may be perceived by women as a legitimate way of expressing distress and getting attention (Aday, 1994). The findings, however, are inconsistent (e.g., Collins et al., 2004; Landau \& Litwin, 2000).

Kellermann (2001) suggested that the experiences during the war were fundamentally different for children and for adults. Children experienced the war at various stages of their cognitive, emotional, and personal development and adopted extraordinary survival strategies. Psychodynamic and other developmental theories suggest that severe adversity in childhood, including the loss of early attachment figures, has pathological consequences (Bowlby, 1973; Nelson et al., 2007). Keilson (1992) maintained that the younger the child was during the traumatic period, the greater the damage to personality development; hence, child survivors should be at greater eventual risk than adult survivors. Some, however, have pointed to the potential for resilience in children. For example, Kadushin (1976) suggested that children possess varying capacities for coping with potentially traumatic conditions that enable them to overcome the damaging influences of earlier difficulties in development. These capacities or sources of resilience include intrapsychic and cognitive protective factors. The intrapsychic view is based on a structural psychodynamic model and suggests that defense mechanisms, particularly repression of negative childhood experiences, may facilitate long-term adaptation (Sigal \& Weinfeld, 2001). The cognitive factor suggests that children have a limited ability to process life-threatening situations, and it is only in adolescence that they become capable of perceiving their vulnerability to potentially life-threatening events (Fletcher, 1996; Sigal \& Weinfeld, 2001). Figure 1 provides a general model of the several factors that may influence pathology, coping, and resilience among Holocaust survivors.

In sum, there is considerable variation in approach and methodology of Holocaust studies. The general impression that emerges 


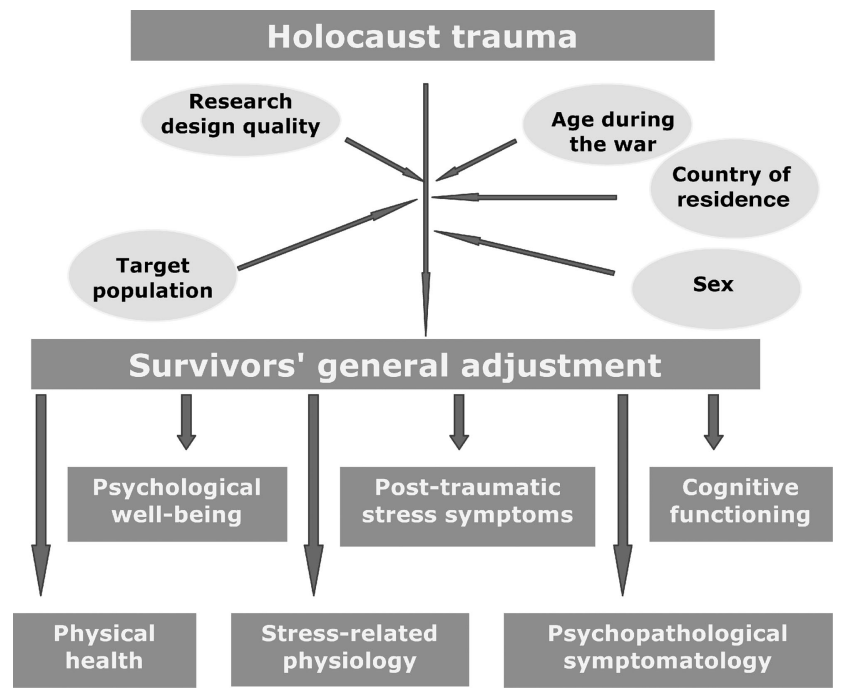

Figure 1. Model of Holocaust survivors' adjustment in several domains of functioning.

from inspecting the literature is that empirical studies with nonconvenience sampling tend to focus more on the adaptive capacities of Holocaust survivors (Lomranz, 1995). Clinically oriented studies, based on psychodynamic theories and using selected samples, more often find psychopathology and lack of adaptation in Holocaust survivors (Kahana et al., 1988).

The variation in outcomes requires a more fine-tuned examination of the adjustment of Holocaust survivors, in which the validity of the available studies is carefully weighed. Moreover, findings may diverge for various domains of functioning, with some domains more affected than other domains by the atrocious experiences. These issues are addressed in a series of meta-analyses as a quantitative account of the outcomes reported in the various studies.

\section{The Present Study: Overview and Research Questions}

A few narrative reviews of the Holocaust survivors' literature have been published in the past years. Some of the reviews were conducted as a direct evaluation of the Holocaust literature (e.g., Kellermann, 2001; Sigal, 1995) and others as part of examining the long-term effects of trauma exposure (e.g., Sadavoy, 1997), but all used the traditional narrative approach. Therefore, a meta-analytic review taking into account moderators that explain variation in study outcomes (Kellermann, 2001) is needed in order to reach a more solid conclusion regarding the long-term effects of the Holocaust on survivors.

Two meta-analyses have investigated secondary and tertiary traumatization in Holocaust survivor families, with an essential distinction between select versus nonselect and between clinical versus nonclinical studies. Van IJzendoorn et al. (2003) did not find evidence for secondary traumatization in nonselect and nonclinical samples, although secondary traumatization emerged in clinical and select samples. Sagi-Schwartz, Van IJzendoorn, and Bakermans-Kranenburg (2008) did not find evidence for tertiary traumatization in Holocaust families (i.e., negative effects of Holocaust-related traumatic experiences of survivors on their grandchildren were absent). Sagi-Schwartz et al. interpreted these findings as a sign of resilience on the part of the Holocaust survivors in their parental roles, even when they were profoundly traumatized personally.

In light of the remarkable findings of these meta-analytic studies, and especially because of the assertions regarding survivor resilience in their parental roles, it is necessary to determine whether this resilience is also apparent in other areas of the survivors' functioning or whether it is restricted to the parental role. In the current study, we attempt to address this question and to uncover whether in various domains of psychological adjustment the trauma is manifest as psychopathology.

\section{Research Questions}

The current meta-analysis addresses the following central questions (see Figure 1):

1. Does the Holocaust affect the survivors' general adjustment?

2. Does study design, in particular the sampling method (select/nonselect) employed and target population (clinical/nonclinical) chosen, explain the diverging results in general adjustment and its components?

3. Does the Holocaust experience affect survivors differentially across disparate domains of functioning, namely, physical health, psychological well-being, posttraumatic stress symptoms, psychopathological symptomatology, cognitive functioning, and stress-related physiology?

4. Does any moderating effect of sex, country of residence, or age during the war explain the diverging results in general adjustment and its components?

\section{Method}

\section{Data Collection}

Studies were collected using three search strategies (Mullen, 1989; Rosenthal, 1991). First, PsychINFO, MEDLINE, and PILOTS (a comprehensive database on posttraumatic stress) were searched with Holocaust and survivor*' used as keywords. Second, the references of the collected papers, books, and book chapters were searched for relevant Holocaust studies. Third, recent narrative reviews were used as a source for relevant papers, in particular those of Kellermann (2001) and Sadavoy (1997).

The selection criteria were broad, to ensure inclusion of as many Holocaust studies as possible, regardless of research design and platform of publication. We included all formal platforms, such as journals, books, and $\mathrm{PhD}$ dissertations. One important criterion was that the study should contain at least one comparison group that presented data from which to derive the pertinent metaanalytic statistics. The nature of comparison groups varied across studies. For example, some studies matched on background characteristics, except for the Holocaust experience (e.g., in Baider, Peretz and Kaplan De-Nour, 1992, all participants, Holocaust survivors and comparisons, were cancer patients); whereas other studies compared Holocaust survivors to other European-born 
Jews who did not undergo the Holocaust (e.g., Collins et al., 2004). In other studies comparison groups were included regardless of whether they immigrated from Europe (e.g., Ben-Zur \& Zimmerman, 2005). Studies without a comparison group, case studies, and qualitative publications were excluded because they did not meet the criteria of the meta-analysis approach. Our search revealed hundreds of papers (about 1,300 in PsychINFO, 1,300 in PILOTS, and 300 in MEDLINE; dozens more were reached and examined through their reference lists). Only 59 met the criteria for inclusion in the meta-analysis. Twelve studies included multiple samples. For an overview of the studies that were included, see Table 1.

\section{Coding System}

A coding system was used to rate each Holocaust study with respect to design, sample, and measurement characteristics. We coded sample size (Holocaust survivors and comparisons) and design characteristics (recruitment method). On recruitment method, studies were coded as "nonselect" when participants were randomly sampled (e.g., from several neighborhoods or a population registry) or when the entire Jewish population of a certain country, region, or institution (e.g., hospital) was involved. Studies were coded as "select" when samples were recruited through, for example, Holocaust survivor meetings, personal contacts, or advertisement. We coded whether the sample was clinical or nonclinical, and we recorded the current country of residence of the sample (Israel, Canada, United States, or Australia).We also coded sex (male, female, or mixed) and the age of the survivors during the war. Age was coded as "children" if the survivors were under the age of 16 at the end of the war and as "adults" if they were above 16 (as is customary in the field; see, e.g., M. Cohen et al., 2001). Some studies were coded as "mixed." Other potential moderators, such as birth country and nature of Holocaust experiences (e.g., concentration camps vs. hiding), could not be coded because the studies did not provide sufficient information.

Finally, we coded the type of outcome as follows: psychological well-being, posttraumatic stress symptoms (PTSS), psychopathological symptomatology, physical health, cognitive functioning, and stress-related physiology (SRP). We defined psychological well-being as general social adaptation or personality development. Indicators were, for example, the Tennessee Self-Concept (Fitts, 1971) measuring positive self-regard (e.g., Gay, 1982). PTSS was defined as re-experiencing of trauma, numbing of responsiveness, and reduced involvement with the external world. The measures of PTSD included the Impact of Event Scale (Horowitz, Wilner, \& Alvarez, 1979; e.g., in Baider et al., 1992) or the Endler Multidimensional Anxiety Scales (Endler, Lobel, Parker, \& Schmitz, 1991; e.g., in Sagi-Schwartz et al., 2003). Psychopathological symptomatology included all symptoms of malfunctioning and maladaptation, anxiety, or depression, excluding PTSS. Measures included the Symptom Checklist 90 (Derogatis, 1977; e.g., in Kahana et al., 1997) or the Beck Depression Inventory (Beck, Rial, \& Rickels, 1974; e.g., in Isaacowitz, Smith, and Carstensen, 2003). Physical health was defined in terms of objective and subjective measures of physical health indicated by, for example, diastolic blood pressure (e.g., in Carmil \& Carel, 1986) and self-rated health (e.g., in Shmotkin \& Lomranz, 1998). Cognitive functioning included several intelligence and memory measures, such as the Mini-Mental State Examination (Folstein, Folstein, \& McHugh, 1975; e.g., in Conn, Clarke, \& Van Reekum, 2000), Wechsler Adult Intelligence Scale-Revised (Wechsler, 1981; e.g., in Yehuda et al., 2005), and Guild Memory Test (Gilbert, Levee, \& Catalano, 1968; e.g., in Golier et al., 2005). SRP included measures of hippocampus volume using magnetic resonance imaging (e.g., in Golier et al., 2005) and cortisol level using, for example, urine collection (e.g., Yehuda, Kahana, Binder-Brynes, et al., 1995).

The following additional decisions were made:

1. When data for the same participants were reported in different studies, only one study was selected based on relevance to the investigated outcome in our metaanalysis.

2. If one comparison group was compared with two or more Holocaust groups within the same study, the number of comparison participants was divided accordingly, to avoid inflating the number of participants.

3. If the Holocaust group was compared with two comparison groups, we combined the two comparison groups or chose only one of them based on group characteristics, availability of statistics to compute averages across comparison groups, and relevance to our meta-analysis.

4. Samples were classified as clinical when the group was exposed to some clinical treatment or intervention. If the authors divided the Holocaust group into clinical and nonclinical groups based on the specific instrument used in the study and not on clinical intervention exposure, we did not treat this group as clinical in our study.

Intercoder reliability (AS and EB) on outcomes (psychological well-being, PTSS, psychopathological symptomatology, physical health, cognitive functioning, SRP) and moderator variables (gender, clinical/nonclinical, age during the war, country of residence), established on a random selection of $20 \%$ of the studies included in the meta-analysis, was satisfactory $(k=14$ studies, mean $\kappa=$ .89 , range $=0.71-1.00)$. Disagreements in coding were resolved through discussion by reaching consensus between coders.

\section{Data Analysis}

The findings referring to the outcomes reported in the studies included means, standard deviations, and correlations. These were inserted into Borenstein, Rothstein, and Cohen's (2000) Comprehensive Meta-Analysis program. Because the studies included in this series of meta-analyses reported various statistics, the outcomes of all studies were recomputed and transformed into Cohen's $d$ (the standardized difference in means between Holocaust survivors and comparisons). When more than one outcome was reported, the outcomes were metaanalytically combined into one effect size (i.e., Cohen's $d$ ). Moreover, an overall effect size for general adjustment based on available indicators for psychological well-being, PTSS, psychopathological symptomatology, physical health, cognitive functioning, and SRP was computed for each study to avoid counting a study or participant more than once. The $Q$ for the 
Table 1

Studies on the Long-Term Consequences of the Holocaust on Survivors

\begin{tabular}{|c|c|c|c|c|c|c|c|}
\hline Study & $N$ & Recruitment & $\begin{array}{c}\text { Target } \\
\text { population }\end{array}$ & Sex & $\begin{array}{l}\text { Country of } \\
\text { residence }\end{array}$ & $\begin{array}{l}\text { Age during } \\
\text { war }\end{array}$ & Outcome \\
\hline Amir \& Lev-Wiesel (2003) & 87 & Select & Nonclinical & Mixed & Israel & Children & $\begin{array}{l}\text { Psychological well-being, physical } \\
\text { health, PTSS, symptomatology }\end{array}$ \\
\hline \multirow[t]{2}{*}{ Assael \& Givon (1984) } & 28 & Nonselect & Clinical & Male & Israel & Adults & Physical health, symptomatology \\
\hline & 41 & Nonselect & Clinical & Female & Israel & Adults & Physical health, symptomatology \\
\hline Bachar et al. (2005) & 98 & Select & Nonclinical & Mixed & Israel & Mixed & Symptomatology \\
\hline Baider et al. (1992) & 106 & Nonselect & Clinical & Mixed & Israel & Mixed & $\begin{array}{l}\text { Psychological well-being, PTSS, } \\
\text { symptomatology }\end{array}$ \\
\hline Barak et al. (2005) & 921 & Nonselect & Clinical & Mixed & Israel & Mixed & Symptomatology \\
\hline Ben-Zur \& Zimmerman (2005) & 90 & Nonselect & Nonclinical & Mixed & Israel & Mixed & $\begin{array}{l}\text { Psychological well-being, physical } \\
\text { health }\end{array}$ \\
\hline Breslau (2002) & 137 & Select & Nonclinical & Mixed & United States & Mixed & $\begin{array}{l}\text { Psychological well-being, PTSS, } \\
\text { symptomatology }\end{array}$ \\
\hline Brody (1999) & 40 & Select & Nonclinical & Mixed & United States & Children & PTSS symptomatology \\
\hline Carmil \& Breznitz (1991) & 253 & Nonselect & Nonclinical & Mixed & Israel & & Psychological well-being \\
\hline \multirow[t]{2}{*}{ Carmil \& Carel (1986) } & 2,121 & Nonselect & Nonclinical & Male & Israel & Adults & $\begin{array}{l}\text { Psychological well-being, physical } \\
\text { health, symptomatology }\end{array}$ \\
\hline & 1,188 & Nonselect & Nonclinical & Female & Israel & Adults & $\begin{array}{l}\text { Psychological well-being, physical } \\
\text { health, symptomatology }\end{array}$ \\
\hline Cassel \& Suedfeld (2006) & 66 & Select & Nonclinical & Mixed & Canada & Children & Psychological well-being, PTSS \\
\hline Clarke et al. (2004) & 530 & Nonselect & Clinical & Mixed & Canada & Mixed & Symptomatology \\
\hline \multirow[t]{2}{*}{ E. Cohen et al. (2003) } & 64 & Select & Clinical & Mixed & Israel & Children & Psychological well-being, PTSS \\
\hline & 70 & Select & Nonclinical & Mixed & Israel & Children & Psychological well-being, PTSS \\
\hline K. Cohen \& Shmotkin (2007) & 201 & Select & Nonclinical & Mixed & Israel & Mixed & Psychological well-being \\
\hline M. Cohen et al. (2001) & 100 & Nonselect & Nonclinical & Mixed & Israel & Children & $\begin{array}{l}\text { Psychological well-being, PTSS, } \\
\text { symptomatology }\end{array}$ \\
\hline \multirow[t]{2}{*}{ Collins et al. (2004) } & 332 & Nonselect & Nonclinical & Male & Israel & Adults & $\begin{array}{l}\text { Psychological well-being, physical } \\
\text { health, symptomatology }\end{array}$ \\
\hline & 442 & Nonselect & Nonclinical & Female & Israel & Adults & $\begin{array}{l}\text { Psychological well-being, physical } \\
\text { health, symptomatology }\end{array}$ \\
\hline Conn et al. (2000) & 472 & Nonselect & Clinical & Mixed & Canada & Mixed & PTSS, symptomatology \\
\hline de Vries et al. (2005) & 74 & Select & Nonclinical & Mixed & Canada & Children & Psychological well-being \\
\hline \multirow[t]{2}{*}{ Eaton et al. (1982) } & 183 & Nonselect & Nonclinical & Male & Canada & Mixed & $\begin{array}{l}\text { Psychological well-being, physical } \\
\text { health }\end{array}$ \\
\hline & 72 & Nonselect & Nonclinical & Female & Canada & Mixed & $\begin{array}{l}\text { Psychological well-being, physical } \\
\text { health }\end{array}$ \\
\hline Fenig \& Levav (1991) & 96 & Nonselect & Nonclinical & Female & Israel & Mixed & Symptomatology \\
\hline Gay (1982) & 52 & Nonselect & Clinical & Mixed & Israel & Mixed & Psychological well-being \\
\hline Golier et al. (2005) & 47 & Select & Nonclinical & Mixed & United States & Children & Cognitive functioning, SRP \\
\hline Goodman et al. (2007) & 15 & Nonselect & Clinical & Mixed & Israel & Children & $\begin{array}{l}\text { PTSS, symptomatology, cognitive } \\
\text { functioning }\end{array}$ \\
\hline Hantman \& Solomon (2007) & 200 & Nonselect & Clinical & Mixed & Israel & Mixed & $\begin{array}{l}\text { Psychological well-being, PTSS, } \\
\text { symptomatology }\end{array}$ \\
\hline Harel et al. (1988) & 340 & Nonselect & Nonclinical & Mixed & Israel & Mixed & $\begin{array}{l}\text { Psychological well-being, physical } \\
\text { health }\end{array}$ \\
\hline Isaacowitz et al. (2003) & 32 & Select & Nonclinical & Female & United States & Mixed & $\begin{array}{l}\text { Psychological well-being, PTSS, } \\
\text { symptomatology }\end{array}$ \\
\hline Joffe et al. (2003) & 150 & Nonselect & Nonclinical & Mixed & Australia & Mixed & $\begin{array}{l}\text { Psychological well-being, physical } \\
\text { health, PTSS, symptomatology }\end{array}$ \\
\hline Kahana et al. (1997) & 323 & Nonselect & Nonclinical & Mixed & United States & Mixed & $\begin{array}{l}\text { Psychological well-being, PTSS, } \\
\text { symptomatology }\end{array}$ \\
\hline Kaminer \& Lavie (1991) & 33 & Select & Mixed & Mixed & Israel & Children & $\begin{array}{l}\text { Psychological well-being, } \\
\text { symptomatology }\end{array}$ \\
\hline Kapeliuk (1995) & 90 & Select & Nonclinical & Female & United States & Mixed & $\begin{array}{l}\text { Psychological well-being, physical } \\
\text { health, symptomatology }\end{array}$ \\
\hline Kohn Dor-Shav (1978) & 62 & Nonselect & Nonclinical & Mixed & Israel & Mixed & $\begin{array}{l}\text { Psychological well-being, } \\
\text { cognitive functioning }\end{array}$ \\
\hline \multirow[t]{2}{*}{ Landau \& Litwin (2000) } & 111 & Nonselect & Nonclinical & Male & Israel & Adults & $\begin{array}{l}\text { Psychological well-being, physical } \\
\text { health, PTSS, symptomatology }\end{array}$ \\
\hline & 83 & Nonselect & Nonclinical & Female & Israel & Adults & $\begin{array}{l}\text { Psychological well-being, physical } \\
\text { health, PTSS, symptomatology }\end{array}$ \\
\hline Letzter-Pouw \& Werner (2003) & 168 & Select & Nonclinical & Mixed & Israel & Mixed & Physical health, symptomatology \\
\hline Lev-Wiesel \& Amir (2003) & 87 & Select & Clinical & Mixed & Israel & Children & $\begin{array}{l}\text { Psychological well-being, PTSS, } \\
\text { symptomatology }\end{array}$ \\
\hline
\end{tabular}


Table 1 (continued)

\begin{tabular}{|c|c|c|c|c|c|c|c|}
\hline Study & $N$ & Recruitment & $\begin{array}{c}\text { Target } \\
\text { population }\end{array}$ & Sex & $\begin{array}{l}\text { Country of } \\
\text { residence }\end{array}$ & $\begin{array}{l}\text { Age during } \\
\text { war }\end{array}$ & Outcome \\
\hline \multirow[t]{2}{*}{ Marcus \& Menczel (2007) } & 95 & Select & Nonclinical & Female & Israel & Children & Physical health \\
\hline & 38 & Select & Nonclinical & Female & Israel & Adults & Physical health \\
\hline Nadler \& Ben-Shushan (1999) & 68 & Nonselect & Nonclinical & Mixed & Israel & Mixed & $\begin{array}{l}\text { Psychological well-being, } \\
\text { symptomatology }\end{array}$ \\
\hline Nathan et al. (1964) & 277 & Nonselect & Clinical & Mixed & Israel & Mixed & Symptomatology \\
\hline \multirow{2}{*}{ Peretz et al. (1994) } & 82 & Nonselect & Clinical & Female & Israel & Adults & Symptomatology \\
\hline & 69 & Select & Nonclinical & Female & Israel & Adults & Symptomatology \\
\hline Prager \& Solomon (1995) & 160 & Nonselect & Nonclinical & Mixed & Israel & Mixed & Psychological well-being \\
\hline \multirow[t]{2}{*}{ Robinson et al. (1994) } & 54 & Nonselect & Clinical & Mixed & Israel & Mixed & PTSS \\
\hline & 61 & Select & Nonclinical & Mixed & Israel & Mixed & PTSS \\
\hline Rosen et al. (1991) & 96 & Select & Nonclinical & Mixed & United States & Mixed & PTSS \\
\hline Sagi et al. (2002) & 81 & Select & Nonclinical & Mixed & Israel & Mixed & Psychological well-being, PTSS \\
\hline Sagi-Schwartz et al. (2003) & 98 & Nonselect & Nonclinical & Female & Israel & Children & Psychological well-being, PTSS \\
\hline \multirow[t]{2}{*}{ Shafir et al. (1975) } & 140 & Select & Clinical & Mixed & Israel & Mixed & Psychological well-being \\
\hline & 44 & Select & Clinical & Mixed & Israel & Mixed & Psychological well-being \\
\hline Shanan \& Shahar (1983) & 64 & Nonselect & Nonclinical & Mixed & Israel & Adults & $\begin{array}{l}\text { Psychological well-being, } \\
\text { cognitive functioning }\end{array}$ \\
\hline \multirow[t]{2}{*}{ Shmotkin \& Lomranz (1998) } & 422 & Nonselect & Nonclinical & Mixed & Israel & Mixed & $\begin{array}{l}\text { Psychological well-being, physical } \\
\text { health, symptomatology }\end{array}$ \\
\hline & 254 & Select & Nonclinical & Mixed & Israel & Mixed & $\begin{array}{l}\text { Psychological well-being, physical } \\
\text { health, symptomatology }\end{array}$ \\
\hline Soskolne et al. (2005) & 107 & Nonselect & Clinical & Male & Israel & Children & $\begin{array}{l}\text { Psychological well-being, physical } \\
\text { health }\end{array}$ \\
\hline Suedfeld (2003) & 93 & Select & Nonclinical & Mixed & Mixed & Mixed & Psychological well-being \\
\hline \multirow[t]{2}{*}{ Suedfeld et al. (2005) } & 115 & Select & Nonclinical & Mixed & United States & Children & Psychological well-being \\
\hline & 95 & Select & Nonclinical & Mixed & United States & Mixed & Psychological well-being \\
\hline Terno et al. (1998) & 74 & Nonselect & Clinical & Mixed & Israel & Mixed & Symptomatology \\
\hline Trappler et al. (2007) & 38 & Nonselect & Clinical & Mixed & United States & Mixed & $\begin{array}{l}\text { Psychological well-being, PTSS, } \\
\text { symptomatology }\end{array}$ \\
\hline Yaari et al. (1999) & 66 & Nonselect & Clinical & Mixed & Israel & Mixed & $\begin{array}{l}\text { Psychological well-being, physical } \\
\text { health, symptomatology }\end{array}$ \\
\hline Yehuda et al. (1996) & 76 & Select & Nonclinical & Mixed & United States & Mixed & $\begin{array}{l}\text { Psychological well-being, PTSS, } \\
\text { symptomatology }\end{array}$ \\
\hline Yehuda et al. (2004) & 102 & Select & Nonclinical & Mixed & United States & Children & Cognitive functioning \\
\hline Yehuda et al. (2005) & 63 & Select & Nonclinical & Mixed & $\begin{array}{l}\text { United States, } \\
\text { Canada }\end{array}$ & Children & PTSS, cognitive functioning, SRP \\
\hline Yehuda et al. (2002) & 50 & Select & Nonclinical & Mixed & United States & Children & PTSS, symptomatology, SRP \\
\hline \multicolumn{8}{|l|}{ Yehuda, Kahana, Binder- } \\
\hline Brynes, et al. (1995) & 62 & Select & Nonclinical & Mixed & United States & & PTSS, SRP \\
\hline \multicolumn{8}{|l|}{ Yehuda, Kahana, Schmeidler } \\
\hline $\begin{array}{l}\text { et al. (1995) } \\
\text { Yehuda et al. (1994) }\end{array}$ & 91 & Select & Nonclinical & Mixed & United States & Mixed & Psychological well-being, PTSS \\
\hline & 41 & Select & Nonclinical & Mixed & United States & Mixed & Symptomatology \\
\hline
\end{tabular}

Note. $\quad$ PTSS $=$ posttraumatic stress symptoms; symptomatology $=$ psychopathological symptomatology; SRP $=$ stress-related physiology.

comparison of the combined effect sizes was used in order to compare the combined effects sizes of two or more subsets of studies. In moderator analyses, subsets of fewer than four studies were excluded to avoid unstable outcomes (BakermansKranenburg, Van IJzendoorn, \& Juffer, 2003). This calculation is based on the logic of analysis of variance, with the total variance $Q_{\text {total }}$ partitioned into $Q_{\text {between }}$ and $Q_{\text {within }} . Q_{\text {total }}$ is the variance with any grouping factors ignored, and $Q_{\text {within }}$ for each group refers to the variances in the specific subsets of studies. $Q_{\text {between }}$ equals $Q_{\text {total }}-Q_{\text {within }}$ and is tested for significance with the chi-square distribution (Borenstein, Hedges, Higgins, $\&$ Rothstein, 2009). A significant $Q$ value for the comparison indicates that the difference in effect size between subsets of studies is significant.

With the Comprehensive Meta-Aanalysis program we computed fixed- and random-effect model parameters and confidence intervals around the point estimate of an effect size. Because the leading hypothesis in this area of research is that Holocaust survivors would be less well adapted, we used this directed hypothesis and present the $95 \%$ confidence boundaries of the point estimates for the effect sizes. Significance tests and moderator analyses in fixed-effects models are based on the assumption that differences between studies leading to differences in effects are not random and that in principle the set of study effect sizes is homogeneous at the population level. Significance testing is based on the total number of subjects, but generalization is restricted to other participants who might have been included in the same studies of the meta-analysis (Rosenthal, 1995). Statistical inferences may be regarded as applying only to the specific set of studies at hand (Hedges, 1994). In random-effects models this assumption is not made (Hedges \& Olkin, 1985), and these models allow for the possibility that each separate study has its own population parameter. In random-effects models significance testing is based only on the total number of studies, and generalization is to the popu- 
lation of studies from which the current set of studies was derived (Rosenthal, 1995). It has been argued that random-effects models reflect more adequately the heterogeneity in behavioral studies and that they use noninflated alpha levels when the requirement for homogeneity has not been met (Hunter \& Schmidt, 2000). In our meta-analyses, several data sets were heterogeneous. In these cases, the random-effects model parameters (significance, confidence intervals) are presented. The tests for homogeneity of study outcomes (homogeneity $Q$ ) were computed as the squared distance of each study from the combined effect, with each value weighted for study precision (based on the inverse variance method). A significant $Q$ value for homogeneity points to a heterogeneous set of studies (Borenstein, Rothstein, \& Cohen, 2005).

In order to examine potential publication bias, which is likely to inflate size effects, we report the "fail-safe $N$ " number of studies that would be needed to reduce the combined effect size to insignificance (i.e., $p>$.05). Rosenthal's (1991) formula was fail-safe $N=\left[k\left(k \bar{z}^{2}-2.706\right)\right] / 2.706$. Rosenthal's (1991) criterion for fail-safe $N$ was $5 k+10$. Moreover, biased combined effect sizes were adjusted through the "trim and fill" method that estimates the number of missing, unpublished studies from the asymmetry detected in a funnel plot (Petticrew \& Roberts, 2006).

The current analyses included 59 studies and 71 samples covering a publication period of 44 years, from 1964 to 2008. Data on 12,749 participants (Holocaust survivors and comparisons) were included. For each of the 71 samples, the standardized difference between the Holocaust and comparison group was transformed into Fisher's $Z$ as an equivalent to the correlation coefficient $r$, with better distribution characteristics (see Mullen, 1989). A test for outlying effect sizes was conducted in the set of Holocaust studies on the basis of standardized $z$ values larger than 3.29 or smaller than -3.29 ( $p<.01$; Tabachnick \& Fidell, 2001). No outlying effect sizes were identified.

\section{Results}

First, we assess the effect of the Holocaust on survivors' general adjustment; next, we test whether differences in effects on general adjustment can be explained by type of recruitment (select vs. nonselect) and explore the effect of this moderator in each domain of functioning. Then, we explore the moderating effects of clinical status, country of residence, sex, and age of the participants within nonselect and select studies. Finally, we focus on nonselect samples and report the domain-specific results and the moderating effects in each domain of functioning. The focus on nonselect samples converged with the two previous meta-analyses on secondary and tertiary Holocaust traumatization (Sagi-Schwartz et al., 2008; Van IJzendoorn et al., 2003), as they are the most adequately designed studies.

\section{General Adjustment}

In the total set of 71 samples a significant difference was found between Holocaust survivors and comparisons in general adjustment. The combined effect size was a Cohen's $d$ of $0.36, p<.01$, 95\% CI [0.28, 0.43] (see Table 2). The fail-safe number for this effect size was 4,129; that is, 4,129 studies with null results would be necessary to cancel out the combined effect size. The funnel plot showed that there was some publication bias. Fifteen studies had to be trimmed and replaced, resulting in an adjusted effect of $d=0.24,95 \%$ CI $[0.16,0.32]$. Based on the overall effect size for general adjustment in each sample, Holocaust survivors did not adapt as well as did comparisons.

When the studies were divided into subsets with select and nonselect samples, a significant difference in effect size was found. The 34 select samples, including 2,943 participants, showed a nearly medium and significant combined effect size of $d=0.45$,

Table 2

Meta-Analytic Results for Holocaust Survivors and Comparisons: Total Adjustment

\begin{tabular}{|c|c|c|c|c|c|c|c|}
\hline Variable & $k$ & $N$ & $d$ & $95 \% \mathrm{CI}$ & Homogeneity $Q$ & Contrast $Q$ & Contrast $p$ \\
\hline Total adjustment & 71 & 12,746 & $0.36^{* * a \mathrm{a}}$ & {$[0.28,0.43]$} & $260.38^{* *}$ & & \\
\hline Sex & & & & & & $\begin{array}{l}4.62 \\
2.15^{\mathrm{a}}\end{array}$ & $\begin{array}{l}.10 \\
.14\end{array}$ \\
\hline Male & 6 & 2,882 & 0.00 & {$[-0.07,0.08]$} & 9.79 & & \\
\hline Female & 13 & 2,426 & $0.31^{* * *}$ & {$[0.13,0.48]$} & $29.34^{* * *}$ & & \\
\hline Mixed & 52 & 7,438 & $0.39^{* * *}$ & {$[0.31,0.48]$} & $159.27^{* *}$ & & \\
\hline Country of residence & & & & & & 1.47 & .23 \\
\hline Israel & 46 & 9,625 & $0.33^{\text {*** }}$ & {$[0.23,0.42]$} & $177.95^{* *}$ & & \\
\hline Other & 24 & 3,028 & $0.43^{* * *}$ & {$[0.29,0.57]$} & $65.91^{\text {*** }}$ & & \\
\hline Select vs. nonselect & & & & & & 6.67 & .01 \\
\hline Select & 34 & 2,943 & $0.45^{\text {*** }}$ & {$[0.32,0.59]$} & $94.57^{* *}$ & & \\
\hline Nonselect & 37 & 9,803 & $0.28^{* * *}$ & {$[0.19,0.37]$} & $137.00^{* * *}$ & & \\
\hline Clinical vs. nonclinical & & & & & & 2.41 & .12 \\
\hline Clinical & 20 & 3,382 & $0.45^{* *}$ & {$[0.31,0.60]$} & $45.78^{* *}$ & & \\
\hline Nonclinical & 50 & 9,331 & $0.32^{* * *}$ & {$[0.23,0.40]$} & $183.31^{* *}$ & & \\
\hline Age during war & & & & & & $\begin{array}{l}9.24 \\
6.19^{b}\end{array}$ & $\begin{array}{l}.03 \\
.01\end{array}$ \\
\hline Children & 19 & 1,389 & $0.41^{* * *}$ & {$[0.26,0.56]$} & $39.05^{* *}$ & & \\
\hline Adult & 12 & 4,609 & $0.17^{*}$ & {$[0.01,0.31]$} & $21.84^{* *}$ & & \\
\hline Mixed & 38 & 6,433 & $0.39^{* *}$ & {$[0.30,0.48]$} & $104.16^{* *}$ & & \\
\hline
\end{tabular}

${ }^{\mathrm{a}}$ Adjusted effect size $d=0.24,95 \%$ CI $[0.16,0.32] . \quad{ }^{\mathrm{b}}$ Contrast excluding mixed.

${ }^{*} p<.05$. ** $p<.01$. 
$p<.01,95 \%$ CI $[0.32,0.59]$ for general adjustment. The 37 nonselect samples with nonselect recruitment, including 9,803 participants, showed a smaller but still significant effect size, $d=$ $0.28, p<.01,95 \%$ CI $[0.19,0.37]$. The contrast between the effect sizes was significant, $Q(1)=4.34, p<.05$. Thus, studies with select samples showed a larger effect size than did studies with nonselect samples, but even in nonselect studies Holocaust survivors did not adapt as well as the comparisons (see Table 2).

The fail-safe number for the combined effect size of the 37 nonselect samples was 1,002 (i.e., 1,002 studies with null results would be needed to cancel out the combined effect size). The funnel plot showed that there was some publication bias. Six studies had to be trimmed and replaced, resulting in an adjusted effect of $d=0.22,95 \%$ CI [0.13, 0.31]. The fail-safe number for the combined effect size of the 34 select samples was 1,028 (i.e., 1,028 studies with null results would be needed to cancel out the combined effect size). The funnel plot showed that there was no publication bias.

\section{Moderators}

Clinical status. We computed the combined effect sizes of general adjustment for clinical and nonclinical samples within both sets of nonselect and select studies. Within the nonselect studies, combined effect sizes were significant for clinical and for nonclinical samples, $d=0.38, p<.01,95 \%$ CI [0.24, 0.51] and $d=$ $0.21, p<.01,95 \%$ CI $[0.10,0.31]$ respectively (see Table 3 ), and they were not significantly different from each other, $Q[1]=3.84$, $p=.05$. Similarly, in the set of select studies, combined effect sizes were significant for clinical and for nonclinical samples, $d=$ $0.83, p<.01,95 \% \mathrm{CI}[0.32,1.33]$ and $d=0.41, p<.01,95 \% \mathrm{CI}$ $[0.27,0.55]$ respectively (see Table 3 ), and they were not significantly different from each other, $Q(1)=2.47, p=.29$. Thus, Holocaust survivors in both clinical and nonclinical samples did adapt less well than their comparisons.

Country of residence. Studies were divided into two subsets according to country of residence, Israel versus other countries (Canada, United States, and Australia). Within the nonselect studies, the seven samples from non-Israeli countries, including 1,768 participants, showed a significant combined effect size of $d=$ $0.28, p<.01,95 \%$ CI $[0.18,0.37]$, for general adjustment. The 30 Israeli samples, including 8,035 participants, also showed a significant effect size, $d=0.27, p<.01,95 \%$ CI [0.17, 0.37]. The difference between the effect sizes was not significant, $Q(1)=$ $0.17, p=.68$. Within the set of select studies, the seven samples

Table 3

Meta-Analytic Results for Holocaust Survivors and Comparisons: Total Adjustment for Nonselect and Select Studies

\begin{tabular}{|c|c|c|c|c|c|c|c|}
\hline Variable & $k$ & $N$ & $d$ & $95 \% \mathrm{CI}$ & Homogeneity $Q$ & Contrast $Q$ & Contrast $p$ \\
\hline Nonselect total adjustment & 37 & 9,803 & $0.28^{* * a}$ & {$[0.19,0.37]$} & $138.00^{* *}$ & & \\
\hline Sex & & & & & & $\begin{array}{l}2.76 \\
2.02^{\mathrm{b}}\end{array}$ & $\begin{array}{l}.25 \\
.16\end{array}$ \\
\hline Male & 6 & 2,882 & 0.00 & {$[-0.07,0.08]$} & 9.79 & & \\
\hline Female & 8 & 2,102 & $0.31^{* *}$ & {$[0.13,0.50]$} & $24.58^{* * *}$ & & \\
\hline Mixed & 23 & 4,819 & $0.31^{* *}$ & {$[0.20,0.42]$} & $64.26^{* *}$ & & \\
\hline Country of residence & & & & & & 0.17 & .68 \\
\hline Israel & 30 & 8,035 & $0.27^{* * *}$ & {$[0.17,0.37]$} & $122.57^{* *}$ & & \\
\hline Other & 7 & 1,768 & $0.28^{* * *}$ & {$[0.18,0.37]$} & 9.91 & & \\
\hline Clinical vs. nonclinical & & & & & & 3.84 & .05 \\
\hline Clinical & 16 & 3,047 & $0.38^{* *}$ & {$[0.24,0.51]$} & $28.20^{*}$ & & \\
\hline Nonclinical & 21 & 6,756 & $0.21^{* *}$ & {$[0.10,0.31]$} & $70.80^{* * *}$ & & \\
\hline Age during war & & & & & & $\begin{array}{r}14.63 \\
1.98^{\mathrm{b}}\end{array}$ & $\begin{array}{l}.00 \\
.16\end{array}$ \\
\hline Children & 4 & 320 & $0.33^{*}$ & {$[0.10,0.56]$} & 6.28 & & \\
\hline Adult & 10 & 4,502 & $0.14^{*}$ & {$[0.01,0.27]$} & $19.10^{*}$ & & \\
\hline Mixed & 22 & 4,728 & $0.34^{* *}$ & {$[0.25,0.43]$} & $46.02^{* * *}$ & & \\
\hline Select total adjustment & 34 & 2,943 & $0.45^{* *}$ & {$[0.32,0.59]$} & $94.57^{* *}$ & & \\
\hline Sex & & & & & & 2.77 & .10 \\
\hline Male & & & & & & & \\
\hline Female & 5 & 324 & $0.25^{*}$ & {$[0.03,0.48]$} & 3.86 & & \\
\hline Mixed & 29 & 2,619 & $0.48^{* *}$ & {$[0.34,0.63]$} & $88.74^{* *}$ & & \\
\hline Country of residence & & & & & & 4.33 & .12 \\
\hline Israel & 16 & 1,590 & $0.44^{* *}$ & {$[0.26,0.62]$} & $39.97^{* *}$ & & \\
\hline Other & 7 & 1,260 & $0.49^{* *}$ & {$[0.28,0.70]$} & $48.69^{* *}$ & & \\
\hline Clinical vs. nonclinical & & & & & & 2.47 & .29 \\
\hline Clinical & 4 & 335 & $0.83^{* *}$ & {$[0.32,1.33]$} & $12.00^{* * *}$ & & \\
\hline Nonclinical & 29 & 2,575 & $0.41^{* *}$ & {$[0.27,0.55]$} & $77.30^{* *}$ & & \\
\hline Age during war & & & & & & $1.43^{\mathrm{c}}$ & .70 \\
\hline Children & 15 & 1,069 & $0.42^{* *}$ & {$[0.23,0.62]$} & $32.03^{* * *}$ & & \\
\hline Adult & 2 & 107 & 0.09 & {$[-0.31,0.48]$} & 2.67 & & \\
\hline Mixed & 16 & 1,705 & $0.50^{* * *}$ & {$[0.30,0.70]$} & $56.38^{* *}$ & & \\
\hline
\end{tabular}

Note. For nonselect studies, $k=37, N=9,803$; for select studies, $k=34, N=2,943$.

${ }^{\mathrm{a}}$ Adjusted effect size $d=0.45,95 \%$ CI $[0.32,0.59] . \quad{ }^{\mathrm{b}}$ Contrast excluding mixed. ${ }^{\mathrm{c}}$ Subgroup with $k<4$ excluded from contrast.

${ }^{*} p<.05{ }^{* *} p<.01$. 
from non-Israeli countries, including 1,260 participants, showed a significant combined effect size of $d=0.49, p<.01,95 \%$ CI $[0.28,0.70]$, for general adjustment. The 16 Israeli samples, including 1,590 participants, also showed a significant effect size, $d=0.44, p<.01,95 \%$ CI $[0.26,0.62]$. The difference between the effect sizes was not significant, $Q(1)=4.33, p=.12$. Thus, Holocaust survivors in studies both from Israel and from other countries did not adapt as well as comparison participants (see Table 3), but they were not significantly different from each other.

Sex. Dividing the studies by sex (males, females, and mixed samples) produced divergent outcomes. Within the set of nonselect studies, the six male samples, including 2,882 participants, showed no significant combined effect size, $d=0.00, p=.94,95 \% \mathrm{CI}$ $[-0.07,0.08]$, for general adjustment. Thus, male Holocaust survivors did not display less well-being or adaptation than did their comparison male participants. The eight female samples, including 2,102 participants, showed a significant effect size of $d=0.31$, $p<.01,95 \%$ CI $[0.13,0.50]$, and the 23 mixed-gender samples, including 4,819 participants, showed a significant effect size as well, $d=0.31, p<.01,95 \%$ CI $[0.20,0.42]$. The difference between the effect sizes (males, females, and mixed samples) was not significant, $Q(2)=2.76, p=.25$, nor was the difference between male and female samples, $Q(1)=2.02, p=.16$. Within the select studies, the five female samples, including 324 participants, showed a significant effect size of $d=0.31, p<.05,95 \%$ CI $[0.03,0.48]$, and the 29 mixed-gender samples, including 2,619 participants, showed a significant effect size as well, $d=0.48, p<$ $.01,95 \%$ CI $[0.34,0.63]$. There were no select studies on male samples. The difference between female and mixed samples was not significant, $Q(1)=2.77, p=.10$. Holocaust participants from female and mixed samples apparently did not adapt as well as comparisons (see Table 3), but the difference with male samples was not significant.

Age. In the set of nonselect studies, the four child survivor samples, including 320 participants, showed a significant combined effect size of $d=0.33, p<.01,95 \%$ CI [0.10, 0.56], for general adjustment. The 10 adult survivor samples, including 4,502 participants, also showed a significant but numerically smaller effect size of $d=0.14, p<.05,95 \%$ CI [0.01, 0.27]. The contrast between the effect sizes was not significant, $Q(1)=1.98$, $p=.16$. Neither child nor adult Holocaust survivors adapted as well as comparison participants. The samples containing participants of mixed age during the war showed a significant combined effect size of $d=0.34, p<.01,95 \%$ CI [0.25, 0.43], for general adjustment as well (see Table 3). Within the set of select studies, the 15 child survivor samples, including 1,069 participants, showed a significant combined effect size of $d=0.42, p<.01$, $95 \%$ CI $[0.23,0.62]$, for general adjustment. For the two adult survivor samples, including 107 participants, the effect was not significant, $d=0.09, p=.67,95 \%$ CI $[0.31,0.48]$. The samples containing participants of mixed age during the war showed a significant combined effect size of $d=0.50, p<.01,95 \% \mathrm{CI}$ $[0.30,0.70]$, for general adjustment as well (see Table 3 ), and the difference between the child survivor samples and the mixed-age group was not significant, $Q(1)=1.43, p=.70$.

\section{Domain-Specific Results}

Physical health. In the set of 16 nonselect samples, including 6,233 participants, a significant difference was found in physical health between Holocaust survivors and comparisons. The size of the combined effect was a Cohen's $d$ of $0.16, p<.01,95 \% \mathrm{CI}$ $[0.05,0.27]$ (see Table 4). The fail-safe number for the combined effect size was 65 (i.e., 65 studies with null results would be needed to cancel out the combined effect size). The funnel plot showed that there was some publication bias. Five studies had to be trimmed and replaced, resulting in an adjusted, nonsignificant effect size of $d=0.08,95 \%$ CI [ $-0.03,0.19]$. In other words, in nonselect samples Holocaust survivors did not show poorer physical health than did comparisons. In the set of six select samples, including 1,067 participants, a significant difference was found in physical health between Holocaust survivors and comparisons.

Table 4

Meta-Analytic Results for Holocaust Survivors and Comparisons on Physical Health for Nonselect Samples

\begin{tabular}{|c|c|c|c|c|c|c|c|}
\hline Physical health & $k$ & $N$ & $d$ & $95 \% \mathrm{CI}$ & Homogeneity $Q$ & Contrast $Q$ & Contrast $p$ \\
\hline Total & 16 & 6,233 & $0.16^{* * a}$ & {$[0.05,0.27]$} & $13.95^{* *}$ & & \\
\hline Sex & & & & & & $\begin{array}{l}1.16 \\
0.03^{b}\end{array}$ & $\begin{array}{l}.56 \\
.87\end{array}$ \\
\hline Male & 6 & 2,882 & 0.11 & {$[-0.08,0.30]$} & $17.23^{* *}$ & & \\
\hline Female & 5 & 1,826 & 0.06 & {$[-0.04,0.16]$} & 8.70 & & \\
\hline Mixed & 5 & 1,525 & $0.17^{* *}$ & {$[0.07,0.27]$} & 8.88 & & \\
\hline \multicolumn{8}{|l|}{ Country of residence } \\
\hline Israel & 13 & 5,828 & $0.16^{* *}$ & {$[0.04,0.28]$} & $37.31^{* * *}$ & & \\
\hline Other & 3 & 405 & 0.18 & {$[-0.02,0.38]$} & 4.69 & & \\
\hline Clinical vs. nonclinical & & & & & & 3.70 & .05 \\
\hline Clinical & 4 & 242 & $0.40^{* *}$ & {$[0.14,0.70]$} & 5.65 & & \\
\hline Nonclinical & 12 & 5,991 & $0.12^{*}$ & {$[0.01,0.23]$} & $31.23^{* *}$ & & \\
\hline Age during war & & & & & & $0.24^{\mathrm{c}}$ & .62 \\
\hline Children & 1 & 107 & 0.13 & {$[-0.26,0.52]$} & 0 & & \\
\hline Adult & 8 & 4,346 & 0.14 & {$[-0.01,0.29]$} & $26.69^{* *}$ & & \\
\hline Mixed & 7 & 1,780 & $0.15^{* *}$ & {$[0.05,0.24]$} & 10.56 & & \\
\hline
\end{tabular}

Note. $\quad k=16, N=6,233$.

${ }^{a}$ Adjusted effect size $d=0.08,95 \%$ CI $[-0.03,0.19] . \quad{ }^{\mathrm{b}}$ Contrast excluding mixed. $\quad{ }^{\mathrm{c}}$ Subgroup with $k<4$ excluded from contrast.

${ }^{*} p<.05$. **** $p<.01$. 
The size of the combined effect was a Cohen's $d$ of $0.21, p<.01$, $95 \%$ CI $[0.09,0.33]$. The fail-safe number for the combined effect size was 20. The funnel plot showed that there was some publication bias. Three studies had to be trimmed and replaced, resulting in an adjusted, significant effect size of $d=0.14,95 \% \mathrm{CI}$ $[0.03,0.25]$. In select samples, in contrast to nonselect samples, Holocaust survivors did show poorer physical health than did comparisons.

Psychological well-being. In the set of 26 nonselect samples, including 7,367 participants, a significant difference was found for psychological well-being between Holocaust survivors and comparison participants. The size of the combined effect was a Cohen's $d$ of $0.14, p<.05,95 \%$ CI $[0.03,0.24]$ (see Table 5). The fail-safe number for the combined effect size was 85 , such that 85 studies with null results would be needed to cancel out the combined effect size. The funnel plot showed that there was no publication bias. Holocaust survivors showed poorer psychological well-being than did comparisons participants. In the set of 20 select samples, including 2,122 participants, a significant difference was found for psychological well-being between Holocaust survivors and comparisons. The size of the combined effect was a Cohen's $d$ of $0.32, p<.01,95 \%$ CI [0.12, 0.52]. The fail-safe number for the combined effect size was 179. The funnel plot showed that there was some publication bias. Five studies had to be trimmed and replaced, resulting in an adjusted, nonsignificant effect size of $d=0.16,95 \%$ CI [-0.04, 0.36]. In select samples, in contrast to nonselect samples, Holocaust survivors did not show poorer psychological well-being than did comparisons.

PTSS. In the set of 12 nonselect samples, including 1,763 participants, a large difference in PTSS was found between Holocaust survivors and comparison participants. The size of the combined effect amounted to a Cohen's $d$ of $0.72, p<.01,95 \% \mathrm{CI}$ $[0.46,0.98]$ (see Table 6). The fail-safe number for the combined effect size was 482 ; that is, 482 studies with null results would be needed to cancel out the combined effect size. The funnel plot showed that there was no publication bias. Holocaust survivors showed more symptoms of posttraumatic stress than did comparisons. In the set of 16 select samples, including 1,148 participants, a large difference in PTSS was found between Holocaust survivors and comparisons. The size of the combined effect amounted to a Cohen's $d$ of $1.08, p<.01,95 \%$ CI $[0.71,1.45]$. The fail-safe number for the combined effect size was 967. The funnel plot showed that there was no publication bias. In select studies, consistent with nonselect studies, Holocaust survivors showed more symptoms of post traumatic stress than did comparisons.

Psychopathological symptomatology. In the set of 25 nonselect samples, containing 8,270 participants, a significant difference was found in psychopathological symptomatology between Holocaust survivors and comparison participants. The combined effect size was a Cohen's $d$ of $0.33, p<.01,95 \%$ CI $[0.23,0.44]$ (see Table 7). The fail-safe number for the combined effect size was 772 , meaning that 772 studies with null results would be needed to cancel out the combined effect size. The funnel plot showed that there was some publication bias. Six studies had to be trimmed and replaced, resulting in an adjusted effect of $d=0.24$, $95 \%$ CI $[0.14,0.35]$. That is, in nonselect samples Holocaust survivors showed more psychopathological symptoms than did comparisons. In the set of 14 select samples, containing 1,262 participants, a significant difference was found in psychopathological symptomatology between Holocaust survivors and comparisons. The combined effect size was a Cohen's $d$ of $0.22, p<.05,95 \%$ CI $[0.04,0.39]$. The fail-safe number for the combined effect size was 30 . The funnel plot showed that there was no publication bias. In select studies, consistent with nonselect studies, Holocaust survivors showed more psychopathological symptoms than did comparisons.

Cognitive functioning. In the set of five nonselect samples, containing 769 participants, the difference in cognitive functioning between Holocaust survivors and comparisons was not significant. The size of the combined effect was a Cohen's $d$ of $0.10, p=.21$, $95 \%$ CI $[-0.06,0.26]$ (see Table 8). In the set of four select samples, containing 250 participants, the difference in cognitive functioning between Holocaust survivors and comparisons was significant. The

Table 5

Meta-Analytic Results for Holocaust Survivors and Comparisons on Psychological Well-Being for Nonselect Samples

\begin{tabular}{|c|c|c|c|c|c|c|c|}
\hline Psychological well-being & $k$ & $N$ & $d$ & $95 \% \mathrm{CI}$ & Homogeneity $Q$ & Contrast $Q$ & Contrast $p$ \\
\hline Total & 26 & 7,367 & $0.14^{* \mathrm{a}}$ & {$[0.03,0.24]$} & $89.19^{* *}$ & & \\
\hline Sex & & & & & & $\begin{array}{l}1.82 \\
0.06^{b}\end{array}$ & $\begin{array}{l}.40 \\
.80\end{array}$ \\
\hline Male & 5 & 2,861 & -0.03 & {$[-0.10,0.05]$} & 8.70 & & \\
\hline Female & 5 & 1,889 & 0.01 & {$[-0.09,0.10]$} & 7.07 & & \\
\hline Mixed & 16 & 2,617 & $0.21^{* * *}$ & {$[0.06,0.35]$} & $61.92^{* *}$ & & \\
\hline Country of residence & & & & & & 8.59 & .00 \\
\hline Israel & 21 & 6,588 & 0.06 & {$[-0.04,0.17]$} & $59.66^{* * *}$ & & \\
\hline Other & 5 & 779 & $0.37^{* *}$ & {$[0.23,0.52]$} & 6.98 & & \\
\hline Clinical vs. nonclinical & & & & & & 0.00 & .96 \\
\hline Clinical & 6 & 569 & 0.13 & {$[-0.12,0.38]$} & $13.21^{*}$ & & \\
\hline Nonclinical & 20 & 6,798 & $0.14^{*}$ & {$[0.02,0.26]$} & $75.43^{* *}$ & & \\
\hline Age during war & & & & & & $13.23^{\mathrm{c}}$ & .00 \\
\hline Children & 3 & 305 & 0.01 & {$[-0.22,0.24]$} & 2.36 & & \\
\hline Adult & 6 & 4,277 & -0.04 & {$[-0.10,0.02]$} & 4.48 & & \\
\hline Mixed & 16 & 2,532 & $0.27^{* * *}$ & {$[0.15,0.39]$} & $48.21^{* *}$ & & \\
\hline
\end{tabular}

Note. $\quad k=26, N=7,367$.

${ }^{\mathrm{a}}$ Adjusted effect size $d=0.14,95 \%$ CI [0.03, 0.24]. ${ }^{\mathrm{b}}$ Contrast excluding mixed. $\quad{ }^{\mathrm{c}}$ Subgroup with $k<4$ excluded from contrast.

${ }^{*} p<.05$. **** $p<.01$. 
Table 6

Meta-Analytic Results for Holocaust Survivors and Comparisons on Posttraumatic Stress Symptoms (PTSS) for Nonselect Samples

\begin{tabular}{|c|c|c|c|c|c|c|c|}
\hline PTSS & $k$ & $N$ & $d$ & $95 \% \mathrm{CI}$ & Homogeneity $Q$ & Contrast $Q$ & Contrast $p$ \\
\hline Total & 12 & 1,763 & $0.72^{* * a}$ & {$[0.46,0.98]$} & $63.22^{* *}$ & & \\
\hline \multicolumn{8}{|l|}{ Sex } \\
\hline Male & 1 & 111 & $0.66^{* *}$ & {$[0.27,1.06]$} & 0.00 & & \\
\hline Female & 2 & 181 & $0.57^{* * *}$ & {$[0.26,0.86]$} & 1.94 & & \\
\hline Mixed & 9 & 1,471 & $0.79^{* * *}$ & {$[0.46,1.11]$} & $61.06^{* *}$ & & \\
\hline Country of residence & & & & & & \multirow[t]{3}{*}{0.18} & \multirow{3}{*}{.68} \\
\hline Israel & 8 & 780 & $0.74^{* * *}$ & {$[0.40,1.09]$} & $38.29^{* * *}$ & & \\
\hline Other & 4 & 1,007 & $0.71^{* * *}$ & {$[0.25,1.17]$} & $24.84^{* * *}$ & & \\
\hline \multicolumn{6}{|l|}{ Clinical vs. nonclinical } & \multirow{3}{*}{0.85} & \multirow[t]{3}{*}{0.36} \\
\hline Clinical & 6 & 898 & $0.86^{* *}$ & {$[0.47,1.26]$} & $40.71^{* *}$ & & \\
\hline Nonclinical & 6 & 865 & $0.61^{* *}$ & {$[0.26,0.96]$} & $16.42^{* * *}$ & & \\
\hline \multicolumn{8}{|l|}{ Age during war } \\
\hline Children & 3 & 226 & $1.36^{* *}$ & {$[0.78,1.94]$} & $20.45^{* *}$ & & \\
\hline Adult & 2 & 194 & $0.52^{* *}$ & {$[0.22,0.81]$} & 1.2 & & \\
\hline Mixed & 7 & 1,343 & $0.58^{* *}$ & {$[0.25,0.91]$} & $31.87^{* * *}$ & & \\
\hline
\end{tabular}

Note. $k=12, N=1,763$.

${ }^{\text {a }}$ Adjusted effect size $d=0.72,95 \%$ CI $[0.46,0.98]$.

*** $p<.01$.

size of the combined effect was a Cohen's $d$ of $0.43, p<.01,95 \%$ CI $[0.17,0.69]$. The fail-safe number for the combined effect size was 6. The funnel plot showed that there was some publication bias. One study had to be trimmed and replaced, resulting in an adjusted, significant effect size of $d=0.39,95 \%$ CI [0.15, 0.62]. In select samples, in contrast to nonselect samples, Holocaust survivors functioned more poorly than did comparisons on cognitive tasks.

\section{Are Effects in Various Domains of Functioning of Holocaust Survivors Comparable?}

Given that Holocaust survivors struggled more than comparisons in the domains of PTSS, psychopathological symptom- atology, and psychological well-being, we tested for possible differences between these domains of functioning (see Figure 2). The sets of studies overlapped partially (as some studies reported several outcomes), and it was therefore impossible to compare directly the nonindependent effect sizes across these sets. Instead, $85 \%$ confidence intervals were computed for the point estimates of the combined effect sizes and compared across the sets of studies. Nonoverlapping $85 \%$ confidence intervals can be considered to support the conclusion of a significant difference in combined effect sizes (Van IJzendoorn, Juffer, \& Klein Poelhuis, 2005). In nonselect samples, a combined effect size for PTSS $(k=12)$ of $d=0.72, p<.01,85 \%$ CI $[0.53,0.91]$, was found; for psychopathological symptom-

Table 7

Meta-Analytic Results for Holocaust Survivors and Comparisons on Psychopathological Symptomatology for Nonselect Samples

\begin{tabular}{|c|c|c|c|c|c|c|c|}
\hline Symptomatology & $k$ & $N$ & $d$ & $95 \% \mathrm{CI}$ & Homogeneity $Q$ & Contrast $Q$ & Contrast $p$ \\
\hline Total & 25 & 8,270 & $0.33^{* * a}$ & {$[0.23,0.44]$} & $96.64^{* *}$ & & \\
\hline Sex & & & & & & $\begin{array}{l}5.09 \\
3.87^{\mathrm{b}}\end{array}$ & $\begin{array}{l}.07 \\
.07\end{array}$ \\
\hline Male & 4 & 2,592 & 0.04 & {$[-0.04,0.11]$} & 3.32 & & \\
\hline Female & 6 & 1,932 & $0.36^{* * *}$ & {$[0.15,0.56]$} & $17.87^{* * *}$ & & \\
\hline Mixed & 15 & 3,746 & $0.38^{\text {*** }}$ & {$[0.26,0.51]$} & $40.76^{* *}$ & & \\
\hline Country of residence & & & & & & 0.12 & .73 \\
\hline Israel & 20 & 6,757 & $0.35^{* *}$ & {$[0.23,0.47]$} & $84.38^{* *}$ & & \\
\hline Other & 5 & 1,513 & $0.30^{\text {*** }}$ & {$[0.07,0.53]$} & $12.19^{*}$ & & \\
\hline Clinical vs. nonclinical & & & & & & 3.15 & .08 \\
\hline Clinical & 13 & 2,834 & $0.42^{* *}$ & {$[0.28,0.56]$} & $31.93^{* *}$ & & \\
\hline Nonclinical & 12 & 5,436 & $0.25^{\text {*** }}$ & {$[0.12,0.37]$} & $39.26^{* *}$ & & \\
\hline Age during war & & & & & & & \\
\hline Children & 2 & 115 & 0.32 & {$[-0.06,0.69]$} & 0.69 & $6.49^{\mathrm{c}}$ & .01 \\
\hline Adult & 10 & 4,502 & $0.09^{\text {*** }}$ & {$[0.03,0.15]$} & 15.05 & & \\
\hline Mixed & 13 & 3,653 & $0.42^{* * *}$ & {$[0.30,0.54]$} & $45.57^{* * *}$ & & \\
\hline
\end{tabular}

Note. $\quad k=25, N=8,270$.

${ }^{\mathrm{a}}$ Adjusted effect size $d=0.24,95 \%$ CI $[0.14,0.35] . \quad{ }^{\mathrm{b}}$ Contrast excluding mixed. $\quad{ }^{\mathrm{c}}$ Subgroup with $k<4$ excluded from contrast.

${ }^{*} p<.05$. ${ }^{* *} p<.01$. 
Table 8

Meta-Analytic Results for Holocaust Survivors and Comparisons on Cognitive Functioning for Nonselect Samples

\begin{tabular}{|c|c|c|c|c|c|}
\hline Cognitive functioning & $k$ & $N$ & $d$ & $95 \% \mathrm{CI}$ & Homogeneity $Q$ \\
\hline Total & 5 & 769 & 0.10 & {$[-0.06,0.26]$} & 5.68 \\
\hline $\begin{array}{l}\text { Sex } \\
\quad \text { Male } \\
\text { Female }\end{array}$ & & & & & \\
\hline Mixed & 5 & 769 & 0.10 & {$[-0.06,0.26]$} & 5.68 \\
\hline \multicolumn{6}{|l|}{ Country of residence } \\
\hline Israel & 3 & 147 & 0.19 & {$[-0.16,0.53]$} & 2.61 \\
\hline Other & 2 & 622 & 0.08 & {$[-0.10,0.26]$} & 2.78 \\
\hline \multicolumn{6}{|l|}{ Clinical vs. nonclinical } \\
\hline Clinical & 2 & 495 & 0.02 & {$[-0.19,0.22]$} & 1.95 \\
\hline Nonclinical & 3 & 274 & 0.23 & {$[-0.03,0.48]$} & 2.14 \\
\hline \multicolumn{6}{|l|}{ Age during war } \\
\hline $\begin{array}{l}\text { Children } \\
\text { Adult }\end{array}$ & 1 & 23 & 0.66 & {$[-0.26,1.58]$} & 0 \\
\hline Mixed & 4 & 746 & 0.08 & {$[-0.06,0.26]$} & 4.24 \\
\hline
\end{tabular}

Note. $k=5, N=769$

atology $(k=25)$, a combined effect size of $d=0.33, p<.01$, $85 \%$ CI $[0.26,0.41]$, indicated their significant difference from each other. Furthermore, the $85 \%$ confidence intervals of the effect sizes for the other domains were physical health $[0.08$,
0.24], psychological well-being [0.06, 0.21], and cognitive functioning $[-0.02,0.22]$. Outcomes for PTSS and for psychopathological symptomatology were therefore significantly larger than those of the other domains, with PTSS showing the
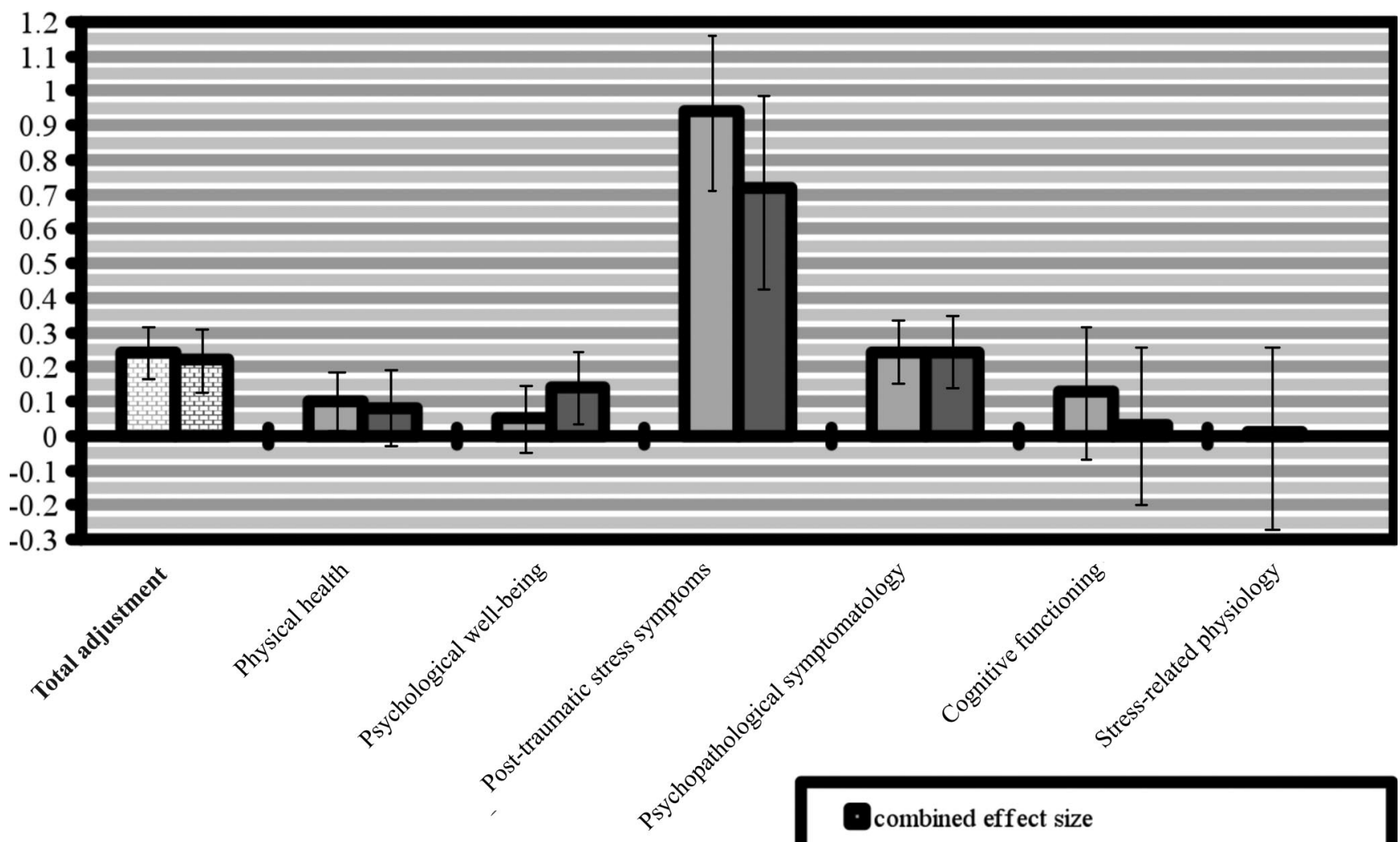

combined effect size

combined effect size excluding select samples

Figure 2. Adjusted effects sizes in total adjustment and for each domain of functioning. Error bars represent standard errors. 
largest effect size and the other three domains not significantly differing from each other.

Previous meta-analyses conducted for the Holocaust survivors' children and grandchildren did not provide evidence for secondary and tertiary traumatization in nonselect samples (Van IJzendoorn et al., 2003, and Sagi-Schwartz et al., 2008, respectively). Given the divergence between the combined effects for select and nonselect studies, with inflated outcomes resulting from the select samples both in the current study and in the previous meta-analysis on Holocaust survivors' children, we decided to focus our moderator analyses on nonselect studies only, given that they are the most adequately designed studies.

\section{Moderators of the Effects in the Various Domains of Functioning}

Clinical status. Examining the effects of clinical status for each domain of functioning, we found significant effect sizes for both clinical and nonclinical samples for physical health (see Table 4), PTSS (see Table 6), and psychopathological symptomatology (see Table 7). The contrast between clinical and nonclinical samples was not significant for these domains of functioning. For psychological well-being, only the effect size for nonclinical samples was significant, whereas the combined effect size for clinical samples was not significant (see Table 5). Similarly, for cognitive functioning the effect size for nonclinical samples was larger than that for clinical samples (see Table 8); the former did not reach significance. No contrasts were computed because of the insufficient number of studies in some cells $(k<4$; BakermansKranenburg et al., 2003).

Country of residence. In examining effects of country of residence, we found significant effect sizes for samples both from Israel and from other countries for PTSS (see Table 6) and psychopathological symptomatology (see Table 7). However, the combined effect size for physical health was not significant for non-Israeli samples (see Table 4). For psychological well-being Israeli samples showed a nonsignificant effect size, $d=0.06, p=$ $.23,95 \%$ CI $[-0.04,0.17]$, whereas for samples from countries other than Israel the combined effect size was $d=0.37, p<.01$, $95 \%$ CI $[0.23,0.52]$. The difference was significant, $Q(1)=8.59$, $p<.01$ (see Table 5). Thus, Holocaust survivors living in countries other than Israel showed less well-being than their counterparts, whereas no difference was found between Israeli Holocaust survivors and their counterparts for the other domains of functioning.

Sex. In examining sex effects for each domain of functioning, we found no significant sex effect for any of the domains. We found a significant effect size for female samples on psychopathological symptomatology and a nonsignificant effect size for male samples. The contrast between men and women was not significant (see Table 7). For PTSS the effect sizes were significant for both men and women (see Table 6), whereas for physical health and for psychological well-being (see Tables 4 and 5, respectively) the effect sizes were not significant for either female or male samples.

Age. Age during the war was not a significant moderator in any domain of functioning. We found a significant effect sizes for child and for adult survivor samples on PTSS (see Table 6). For physical health and for psychological well-being, the combined effect sizes for adult and child survivors were nonsignificant (see
Tables 4 and 5, respectively), whereas for psychopathological symptomatology the effect size was significant only for adults (note, however, that the effect size for child survivors was based on only two studies; see Table 7).

\section{Is Publication Year Associated With the Combined Effect Size?}

To test whether the combined effect sizes were associated with the year of publication, we computed a set of meta-regressions with effect sizes transformed into Fisher's Zs as dependent variables. The analyses included total adjustment and all the specific domains, with year of publication as a continuous independent variable. Year of publication was not associated with the combined effect sizes.

\section{Discussion}

Our first overall finding from a meta-analysis of 71 samples involving thousands of participants was that Holocaust survivors adapted less well than did their counterparts $(d=0.24)$. There was a slightly lower combined effect size in the nonselect studies $(d=$ 0.22 ) and a significantly higher combined effect size in select samples $(d=0.45)$, meaning that more maladaptation was detected in convenience samples. Investigations of select samples showed larger effects than studies with more rigorous designs with nonselected samples. This result was similar to results of other meta-analyses (e.g., those considering Holocaust survivors' offspring but also those in the field of early childhood interventions; see Bakermans-Kranenburg et al., 2003). Studies with select sampling methods, based on survivors' organizations and gatherings or the snowball method of personal referral, run the risk of inflated effect sizes, because survivors who are more affected by their Holocaust experiences are more likely to be involved in these organizations. Although such select studies may contribute to the total picture, they are flawed from the point of view of scientific rigor, and we therefore focused on nonselect samples when exploring the various domains of functioning in more detail.

In such analyses, the effect sizes revealed an important pattern: In almost every domain apart from PTSS (and to a lesser extent psychopathological symptomatology and psychological wellbeing), the effects were rather small and nonsignificant. By contrast, for PTSS, psychological well-being, and psychopathological symptomatology the effect sizes were significant, particularly for PTSS. That is, Holocaust survivors show heightened traumatization coupled with good adaptation in some aspects of functioning, revealing an intriguing and complex pattern.

Previous studies have provided support for the resilience of survivors of trauma, genocide, and persecution (e.g., Ferren, 1999; Rousseau et al., 2003), suggesting that extreme torment does not necessarily result in disorder and that some individuals undergoing extreme trauma might be well adjusted (Lomranz, 1995). The Holocaust literature provides evidence that many survivors did demonstrate resilience and even manifestations of growth (Eitinger \& Major, 1993). Still, we found that Holocaust survivors displayed lower levels of general adaptation than did their counterparts.

Such results may become more comprehensible when separate domains of functioning are taken into consideration. Metaanalyses of potential domain-specific traumatizing effects of the 
Holocaust on survivors yielded consistent results for three domains: We found a large effect size for PTSS $(d=0.72)$, smaller effects for psychopathological symptomatology $(d=0.24)$ and psychological well-being $(d=0.14)$, but no significant effect for physical health, cognitive functioning, and SRP outcomes. Thus, the significant overall effect size for general adjustment is accounted for mainly by the large effect size for PTSS. This pattern of adequate day-to-day adaptation mixed with trauma-related symptoms converges with previous studies, which have also shown that the psychological scars of Holocaust survivors are evident for trauma-specific outcomes (e.g., Baider et al., 1992; Carmil \& Carel, 1986) but have not necessarily precluded good adaptation in other aspects of functioning (Davidson, 1981).

One of the explanations for these findings may be related to defensive mechanisms that Holocaust survivors employed during and after the war. For example, Shanan and Shahar (1983) suggested that the use of successful denial mechanisms helped survivors in repressing their traumatic experiences. Mazor et al. (1990) proposed that the use of defensive mechanisms, such as denial and repression, enabled Holocaust survivors to focus on active adaptation when rebuilding their lives, establishing new homes, and raising new families. Similarly, Sagi et al. (2002) suggested that the preference of some survivors to dismiss attachment-related issues may serve as a defensive strategy to protect themselves against potentially present and future dissatisfaction and distress in close relationships. Alternatively, resilience of survivors in the domains of physical health and cognitive functioning might be considered a prerequisite for successful adaptation to family life and work, despite their elevated symptoms of posttraumatic stress.

Our results highlight the effects of Holocaust experiences, as evidenced by stress-related symptoms, even more than half a century after the war. These findings underscore the extremely traumatic nature of the Holocaust. There has been a growing consensus that not every kind of exposure to trauma necessarily leads to PTSD but that the severity of the trauma is an important factor predicting PTSD (Paris, 2000). The high prevalence of stress-related symptoms among Holocaust survivors highlights the atrocity of the trauma and underscores the extreme nature of Holocaust-related experiences. Moreover, the rather small, but significant, effect sizes found for psychopathological symptomatology and psychological well-being may be explained by the possible link between these two domains and PTSS. The higher prevalence of other psychiatric symptoms supports the comorbidity premise of PTSD: that is, the proneness to develop other psychiatric illnesses jointly with PTSD (Paris, 2000). However, in the current meta-analyses we were not able to estimate associations between the various domains of functioning.

An intriguing question arises: Why do some individuals show a remarkable capacity to overcome adversity, whereas others develop psychopathology (Werner, 2005)? It appears that the strong motivation of Holocaust survivors to rebuild their lives manifested itself primarily in raising families, becoming involved in social activities, and showing achievements on a wide spectrum of social functioning (Joffe et al., 2003; Krell, 1993), all of which played a significant role in forming protective mechanisms. It has been suggested that the foundation of protective mechanisms lies in self-esteem and self-efficacy (Rutter, 1992) and that although such capacities are formed during childhood and adolescence, they are still open to reconstruction during adulthood, mainly by means of available supportive interpersonal relationships and successful social productivity. By dedicating their lives to productivity at work and to raising families, Holocaust survivors may have used or acquired protective mechanisms that served to shield them against dysfunction in several domains. Moreover, specific personality characteristics may be associated with resilience in Holocaust survivors (Ayalon, 2005). Helmreich (1992) detected 10 qualities in Holocaust survivors that may have led them to conduct normal and positive lives notwithstanding the traumatic experiences they had endured. These qualities include flexibility, assertiveness, tenacity, optimism, intelligence, distancing ability, group consciousness, assimilation of the knowledge that they survived, finding meaning in one's life, and courage. On the basis of his analysis, Helmreich indicated that not all of the qualities were found in each survivor but that those who conducted successful lives afterward possessed more of them.

It should be noted that the studies included various measures of PTSS and that participants in the nonclinical studies were not clinically diagnosed as having PTSD. Similarly, the clinical studies included participants diagnosed with various physical and mental illnesses but not necessarily with PTSD. The meta-analytic findings show that Holocaust survivors exhibit markers of posttraumatic stress to a larger extent than do comparison participants, but these markers do not necessarily qualify for a clinical diagnosis that might interfere with conducting a normal life.

\section{Country of Residence: Israel vs. Other Countries}

Examination of potential moderators revealed that target population (clinical or nonclinical), age during the war, and sex had no moderating effects. Yet country of residence did appear to be significant moderator for at least one outcome. Whereas Holocaust survivors both from Israel and from other countries were less well adapted than their counterparts overall, with country of residence failing to serve as a significant moderator, the exception was in the domain of psychological well-being. Holocaust survivors from countries other than Israel showed less well-being and social adaptation than did comparisons, but no difference was found between Israeli Holocaust survivors and Israeli comparisons. Different suggestions have been raised regarding the potentially moderating effect of country of residence, with some favoring adaptation in countries other than Israel and others suggesting the opposite. It should be noted that Holocaust survivors' attempts to immigrate to the pre-State of Israel after the war were met with resistance by the British mandatory government. Also, upon arriving in Israel, Holocaust survivors experienced problems of unemployment, language barriers, and acculturation (Assael \& Givon, 1984). Finally, during the first two decades of the newly founded State of Israel, dominant public opinion was to suppress the Holocaust from the Israeli national consciousness, to stress the strengths of the Israeli citizens, and to emphasize the challenges of building a new society (Shapira, 1998). Despite such difficulties, the present meta-analytic findings suggest that Israeli Holocaust survivors are not less well adapted than non-Israeli survivors. Israeli Holocaust survivors were found to display levels of wellbeing similar to those of their counterparts, whereas in countries other than Israel the psychological well-being of Holocaust survivors seemed to be lower. 
Three possible explanations may be raised for this finding. The first is linked to the strains and stresses inflicted upon Israeli residents for six decades. The intractable existential threat exerted by the ongoing Israeli-Arab conflict may contribute to lower psychological well-being in both Israeli groups, both those with and and those without a Holocaust background, which would explain the absence of difference between the two groups in Israel (Carmil \& Carel, 1986; Collins et al., 2004; Harel et al., 1988; Van IJzendoorn et al., 2003). The second explanation rests on Frankl's (1962) notion of man's search for meaning, which emphasizes the healing power rooted in the motivation to find meaning even in anguish. This idea is especially relevant in the postwar Israeli situation, which has been characterized by a collective vision of building and shaping the Israeli state. Such an optimistic state of mind might have served as a protective factor helping Holocaust survivors achieve a new sense of meaning for their lives (SagiSchwartz et al., 2003). This was not the case for Holocaust survivors who immigrated to countries other than Israel. Yet because nation served as a moderator for psychological well-being only, we should be cautious in interpreting this isolated finding.

A third possible explanation relates to selective resilience factors that can be attributed to Israeli Holocaust survivors (Bachar, Canetti, \& Berry, 2005). Sigal and Weinfeld (1989) suggested that the choice between Israel and other countries as a destination for immigration is in itself a distinctive marker of the difference between Israeli and other Holocaust survivors. Still, many survivors did not immigrate proactively to one place or another; they were instead rescued. Those who were rescued by various Jewish organizations were more likely to go to the pre-State of Israel at the time, especially orphaned children. Those who had relatives throughout the world might have gone to such destinations as their most desired choices. And still for others, who had the option to determine where to go, it is possible that the choice of Israel as a challenging destination in a poor and unsafe pre-state might have been associated with some potential coping characteristics.

\section{The Long-Term Consequences of the Holocaust}

Three meta-analyses have been conducted, one for each generation. The current study addressed the potential traumatization of the Holocaust on survivors themselves, whereas the meta-analysis on Holocaust survivors' children (Van IJzendoorn et al., 2003) and the meta-analysis on Holocaust survivors' grandchildren (SagiSchwartz et al., 2008) aimed to investigate whether secondary and tertiary traumatization exist. Previous studies did not provide unequivocal findings with regard to the transmission of the Holocaust trauma to Holocaust survivors' offspring. For example, some clinical studies stressed the emotional distress transmitted over generations (e.g., Barocas \& Barocas, 1973), but other studies failed to detect evidence for the transmission of psychopathology (e.g., Leon et al., 1981). Bar-On et al. (1998) suggested that these inconsistencies in findings may relate to study characteristics, such as sampling method, research design, and target population (clinical vs. nonclinical). This suggestion turned out to be relevant also for the findings of the present meta-analysis on Holocaust survivors.

The current study explicitly documented the traumatizing longterm consequences of the Holocaust on survivors. In their daily lives, however, Holocaust survivors are not less adaptive than counterparts are. The previous meta-analysis on Holocaust survivors' children further strengthens these findings (Van IJzendoorn et al., 2003). The resilience that Holocaust survivors display in several domains of functioning must also have been evident in their parental role: No evidence for secondary traumatization was found in nonselect, nonclinical samples. Van IJzendoorn et al. concluded that Holocaust survivors managed to protect their children and shield them from being affected by the Holocaust. Secondary traumatization was found only in some clinical samples. This might mean that the children of Holocaust survivors may be more vulnerable to developing posttraumatic stress symptoms only when being offspring of Holocaust surviving parents is accompanied by other traumatic stressors, such as life-threatening experiences.

The Holocaust was a large-scale genocide and one of the most traumatic man-made catastrophes in history, and the atrocities survivors experienced are manifested to this day in various ways. Nevertheless, the three meta-analyses suggest that alongside the profound and disturbing pain, there is also room for growth. A biopsychological stress-diathesis model of PTSD (Paris, 2000) has been proposed as accounting for the absence of transmission of trauma from the Holocaust survivors to their children (Van IJzendoorn et al., 2003) and from them to the survivors' grandchildren (Sagi-Schwartz et al., 2008). This model is especially relevant for the findings in Holocaust survivors in light of the combined resilience and vulnerability they manifest, with a focus on three important factors that determine the intensity and duration of posttraumatic stress: repeated exposure to traumatic events, the presence of a genetic predisposition for PTSD, and the availability of social support in coping with the traumatic experiences.

The first factor concerns the presence or absence of repeated exposure to traumatic stress. Given that the traumatic experiences of Holocaust survivors were not inflicted by their own parents, the Holocaust may not have undermined the feelings of basic trust in their attachment figures (Van IJzendoorn et al., 2003). Both child and adult survivors showed adaptation in their daily lives, which provides evidence for the potentially protective aspects of experiences with attachment figures in the first prewar years even for child survivors.

The stress-diathesis model also implies that Holocaust survivors may not have been genetically biased to develop intense posttraumatic stress reactions (Sagi-Schwartz et al., 2008; Van IJzendoorn et al., 2003), as these responses would have left them vulnerable in their struggle for survival (Schwartz, Dohrenwend, \& Levav, 1994). A recent study (de Quervain et al., 2007) examining Rwandan survivors supports this claim for a genetic role in the predisposition to develop posttraumatic stress reactions. The study found that a deletion variant of the gene $A D R A 2 B$ was related to enhanced emotional memory in healthy Swiss participants and in survivors of the Rwandan civil war. The refugee participants of the Rwandan civil war experienced highly traumatizing situations (e.g., injury, rape). Deletion carriers demonstrated higher scores for reexperiencing symptoms of the traumatic event than did noncarriers. Nevertheless, no association was detected between this genotype and the presence of clinically diagnosed PTSD. In the current meta-analysis survivors showed a high prevalence of PTSS symptoms, but these did not necessarily qualify for a clinical diagnosis of PTSD. We speculate that some Holocaust survivors may have been protected against PTSD, among other potential 
factors, by their genes (Goldberg, True, Eisen, \& Henderson, 1990).

The third factor in a stress-diathesis model concerns the presence or absence of social support to cope with trauma afterward. Holocaust survivors were dedicated to rebuilding their lives by raising families, becoming involved in social activities, and showing achievement in various domains of social functioning (Joffe et al., 2003; Krell, 1993). These activities played a significant role in promoting and establishing protective mechanisms in the form of social acceptance and support. Van IJzendoorn et al. (2003) further pointed to the function of memorials that have been established in Israel and subsequently in other countries to commemorate the victims of the Holocaust and to support survivors and their families. These memorial activities may have constituted important social support for Holocaust survivors. By helping survivors work through the traumatic memories of the past, these activities may have helped prevent the transmission of the Holocaust trauma to the next generations.

\section{Limitations}

The current meta-analysis has several possible limitations. First, studies included in the meta-analysis were rather heterogeneous, as also reflected by heterogeneity in the outcomes even when moderating factors were taken into account. Contributing to heterogeneity is the use of different instruments assessing the same constructs. For example, whereas Fenig and Levav (1991) assessed demoralization by interviews using the Demoralization Scale (Dohrenwend, Shrout, Egri, \& Mendelsohn, 1980), Collins et al. (2004) evaluated demoralization through a structured questionnaire. The variation in instruments can produce different outcomes because of potential differences in detecting effects through indepth interviews versus self-report measures. This example is relevant when discussing the advantages and disadvantages of observational versus self-report methods, which have reportedly produced different outcomes for similar constructs (Kagan, Snidman, Kahn, \& Towsley, 2007).

Another source of heterogeneity was the comparison group recruited in each study. As noted in the Method section, to ensure the inclusion of as many Holocaust studies as possible we implemented a broad set of selection criteria, and the one important criterion was that the study included at least one comparison group. Thus, these broad selection criteria led to differences in the characteristics of the comparison groups. Most studies compared Holocaust survivors with European-born Jews who immigrated to America or to Israel before the war (e.g., Carmil \& Breznitz, 1991; Carmil \& Carel, 1986; Eaton et al., 1982). Other studies included respondents regardless of whether or not they immigrated from Europe (e.g., Ben-Zur \& Zimmerman, 2005).

Furthermore, the current data set included various ages of participants, which is also a function of the time when these studies were conducted (between 1964 and 2007). Some studies examined participants on various outcomes as they approached old age (e.g., Joffe et al., 2003), whereas others examined them in earlier stages in their life cycles (e.g., Shafir, Hirsch, \& Shepps, 1975). The diversity in the age of respondents may affect the outcomes. Aging is a developmental stage presenting its own tasks and challenges (Erikson, 1959). It has been suggested that aging can reactivate extreme early stress, as seen in Holocaust survivors (e.g., Stanford,
1995). In our meta-analysis, we did not find year of publication to be associated with effect sizes, so we did not find a cohort effect. The experience of the Holocaust, however, might have been rather different for the survivors. Their experience might have led to heterogeneity that cannot be accounted for in most (retrospective) studies and that thus remained elusive in our meta-analyses. For all these reasons the current set of studies appeared to be rather heterogeneous, even after moderator analyses. That is why we applied the more conservative meta-analytic approach of the random-effects model if data sets were found to be heterogeneous.

In addition, the relatively small number of studies reporting cognitive functioning (eight studies, five of them with nonselect samples) and stress-related physiology (only four studies) should be mentioned. More studies on these areas of functioning are badly needed if more definite conclusions are to be drawn. Finally, as mentioned before, the current meta-analysis was based on a fair number of studies that met the inclusion criteria, but it omitted many others. The literature excluded from our meta-analyses includes case studies, quantitative studies without comparison group, and qualitative studies. Therefore, it is important to bear in mind that our study provides a quantitative analysis and not an exhaustive narrative review of all available studies on the effect of the Holocaust on survivors.

\section{Conclusions and Future Directions}

Our investigation suggests that Holocaust survivors demonstrate remarkable resilience in adapting to their personal, social, and communal life. This finding is consistent with the new realm of research during the past two decades. It is also inspired by a salutogenic approach, with a focus on the resilience of survivors, on their ability to overcome their traumatic experiences and even to flourish and gain psychological growth (Ayalon, 2005; Cassel \& Suedfeld, 2006; Helmreich, 1992). Nevertheless, the present study also shows that Holocaust survivors still bear the pain of their past in the form of various psychiatric symptoms, especially PTSS. These findings are particularly relevant for child survivors. Most Holocaust survivors alive now, six decades after the end of World War II, were children during the war. The current findings call for special attention to the care of these survivors. As they approach old age, they encounter new challenges, including retirement, declining health, and loss of spouse, that may reactivate their extreme early stresses (Stanford, 1995). Therapeutic interventions may therefore be needed for coping with the reactivated stress (van der Hal-van Raalte, Van IJzendoorn, \& Bakermans-Kranenburg, 2008). Moreover, because the amazing resilience of many Holocaust survivors in various domains of functioning may mask their vulnerabilities and difficulties, policymakers might easily overlook their urgent needs.

Further investigation is needed if we are to understand the underlying mechanisms of protective and risk factors affecting development after the exposure to extreme trauma. The present meta-analytic findings helped uncover some of these factors, such as country of residence (Holocaust survivors from countries other than Israel show less psychological well-being than do Israeli Holocaust survivors). Still, there is a need for further examination of trait characteristics, environmental factors (e.g., social support and sociocultural differences), and genetic factors. 
Finally, in light of the present meta-analytic findings that document traumatization in Holocaust survivors, and of the two previous meta-analyses that have documented no secondary or tertiary traumatization, there is a need to deepen our understanding of the conditions under which traumatization manifests itself (i.e., under extreme stress; Van IJzendoorn et al., 2003). Exploring resilience and vulnerability factors as well as their interplay is essential for uncovering the long-term consequences of exposure to traumatic experiences, not only of Holocaust survivors but also of victims of other, more recent genocides.

\section{References}

References marked with an asterisk indicate studies included in the meta-analysis that are discussed in the text.

Aday, L. A. (1994). Health status of vulnerable populations. Annual Review of Public Health, 15, 487-509. doi:10.1146/annurev.pu.15.050194.002415

American Psychiatric Association. (1980). Diagnostic and statistical manual of mental disorders (3rd ed.). Washington, DC: Author.

American Psychiatric Association. (2000). Diagnostic and statistical manual of mental disorders (4th ed., text rev.). Washington, DC: Author.

*Amir, M., \& Lev-Wiesel, R. (2003). Time does not heal all wounds: Quality of life and psychological distress of people who survived the Holocaust as children. Journal of Traumatic Stress, 16, 295-299. doi: 10.1023/A:1023756326443

Antonovsky, A., Maoz, B., Dowty, N., \& Wijsenbeek, H. (1971). Twentyfive years later: A limited study of the sequelae of the concentration camp experience. Social Psychiatry, 6, 186-193. doi:10.1007/ BF00578367

*Assael, M., \& Givon, M. (1984). The aging process in Holocaust survivors in Israel. American Journal of Social Psychiatry, 4, 32-36.

Ayalon, L. (2005). Challenges associated with the study of resilience to trauma in Holocaust survivors. Journal of Loss and Trauma, 10, 347358. doi:10.1080/15325020590956774

*Bachar, E., Canetti, L., \& Berry, E. M. (2005). Lack of long-lasting consequences of starvation on eating pathology in Jewish Holocaust survivors of Nazi concentration camps. Journal of Abnormal Psychology, 114, 165-169. doi:10.1037/0021-843X.114.1.165

*Baider, L., Peretz, T., \& Kaplan De-Nour, A. (1992). Effects of the Holocaust on coping with cancer. Social Science and Medicine, 34, 11-15. doi:10.1016/0277-9536(92)90061-T

Bakermans-Kranenburg, M. J., Van IJzendoorn, M. H., \& Juffer, F. (2003). Less is more: Meta analysis of sensitivity and attachment interventions in early childhood. Psychological Bulletin, 129, 195-215. doi:10.1037/ 0033-2909.129.2.195

*Barak, Y., Aizenberg, D., Szor, H., Swartz, M., Maor, R., \& Knobler, H. Y. (2005). Increased risk of attempted suicide among aging Holocaust survivors. American Journal of Geriatric Psychiatry, 13, 701-704. doi: 10.1176/appi.ajgp.13.8.701

Barocas, H. A., \& Barocas, C. B. (1973). Manifestations of concentration camp effects on the second-generation. American Journal of Psychiatry, 130, 820-821.

Bar-On, D., Eland, J., Kleber, R. J., Krell, R., Moore, Y., Sagi, A., . . V Van IJzendoorn, M. H. (1998). Multigenerational perspectives on coping with the Holocaust experience: An attachment perspective for understanding the development sequelae of trauma across generations. International Journal of Behavioral Development, 22, 315-338. doi:10.1080/ 016502598384397

Bartholomew, K., \& Horowitz, L. M. (1991). Attachment style among young adults: A test of a four-category model. Journal of Personality and Social Psychology, 61, 226-244. doi:10.1037/0022-3514.61.2.226

Bar-Tur, L., \& Levy-Shiff, R. (1994). Holocaust review and bearing witness as a coping mechanism of an elderly Holocaust survivor. Clinical Gerontologist, 14, 5-16. doi:0.1300/J018v14n03_02
Beck, A. T., Rial, W. Y., \& Rickels, K. (1974). Short form of Depression Inventory: Crossvalidation. Psychological Reports, 34, 1184-1186.

*Ben-Zur, H., \& Zimmerman, M. (2005). Aging Holocaust survivors well-being and adjustment: Associations with ambivalence over emotional expression. Psychology and Aging, 20, 710-713. doi:10.1037/ 0882-7974.20.4.710

Blettner, M., Sauerbrei, W., Schlehofer, B., Scheuchenpflug, T., \& Friedenreich, C. (1999). Traditional reviews, meta-analyses and pooled analyses in epidemiology. International Journal of Epidemiology, 28, $1-9$.

Borenstein, M., Hedges, L. V., Higgins, J. P. T., \& Rothstein, H. R. (2009). Introduction to meta-analysis. Chichester, England: Wiley.

Borenstein, M., Rothstein, D., \& Cohen, J. (2000). Comprehensive MetaAnalysis (Version 1) [Computer software]. Englewood, NJ: Biostat.

Borenstein, M., Rothstein, D., \& Cohen, J. (2005). Comprehensive MetaAnalysis (Version 2) [Computer software]. Englewood, NJ: Biostat.

Bowlby, J. (1973). Attachment and loss: Vol. 2. Separation, anxiety and anger. New York, NY: Basic Books.

Brave Heart, M. Y. (1999). Gender differences in the historical trauma response among the Lakota. Journal of Health and Social Policy, 10, 1-21. doi:10.1300/J045v10n04_01

*Breslau, I. M. (2002). Intergenerational transmission of trauma in Holocaust survivors and their offspring (Unpublished doctoral dissertation). Fairleigh Dickinson University.

Breslau, N., Davis, G. C., Andreski, P., \& Peterson, E. (1991). Traumatic events and post-traumatic disorder in an urban population of young adults. Archives of General Psychiatry, 48, 216-222.

*Brody, J. M. (1999). An assessment of Nazi concentration camp survivors for posttraumatic stress disorder and neuropsychological concomitants (Unpublished doctoral dissertation). California School of Professional Psychology, Alameda.

Butler, L., \& Nolen-Hoeksema, S. (1994). Gender differences in responses to depressed mood in a college sample. Sex Roles, 30, 331-347. doi: 10.1007/BF01420597

*Carmil, D., \& Breznitz, S. (1991). Personal trauma and world view: Are extremely stressful experiences related to political attitudes, religion beliefs, and future orientation? Journal of Traumatic Stress, 4, 393-405. doi:10.1007/BF00974557

*Carmil, D., \& Carel, R. S. (1986). Emotional distress and satisfaction in life among Holocaust survivors: A community study of survivors and controls. Psychological Medicine, 16, 141-149. doi:10.1017/ S0033291700002580

*Cassel, L., \& Suedfeld, P. (2006). Salutogenesis and autobiographical disclosure among Holocaust survivors. Journal of Positive Psychology, 1, 212-225. doi:10.1080/17439760600952919

Chodoff, P. (1963). Late effects of the concentration camp syndrome. Archives of General Psychiatry, 8, 323-333.

Chodoff, P. (1986). Survivors of the Nazi Holocaust. In R. H. Moos (Ed.), Coping with life crises: An integrated approach (pp. 407-415). New York, NY: Plenum Press

*Clarke, D. E., Colantonio, A., Heslegrave, R., Rhodes, A., Lonks, P., \& Conn, D. (2004). Holocaust experience and suicidal ideation in high-risk older adults. American Journal of Geriatric Psychiatry, 12, 65-74. doi:10.1176/ajgp.12.1.65

*Cohen, E., Dekel, R., Solomon, Z., \& Lavie, T. (2003). Posttraumatic stress symptoms and fear of intimacy among treated and non-treated survivors who were children during the Holocaust. Social Psychiatry \& Psychiatric Epidemiology, 38, 611-617. doi:10.1007/s00127-0030681-9

*Cohen, K., \& Shmotkin, D. (2007). Emotional rating of anchor periods in life and their relation to subjective well-being among Holocaust survivors. Personality and Individual Differences, 43, 495-506. doi:10.1016/ j.paid.2006.12.018

*Cohen, M., Brom, D., \& Dasberg, H. (2001). Child survivors of the 
Holocaust: Symptoms and coping after fifty years. Israel Journal of Psychiatry and Related Sciences, 38, 3-12.

*Collins, C., Burazeri, G., Gofin, J., \& Kark, J. D. (2004). Health status and mortality in Holocaust survivors living in Jerusalem 40-50 years later. Journal of Traumatic Stress, 17, 103-411.

*Conn, D. K., Clarke, D., \& Van Reekum, R. (2000). Depression in Holocaust survivors: Profile and treatment outcome in a geriatric day hospital program. International Journal of Geriatric Psychiatry, 15, 331-337. doi:10.1002/(SICI)1099-1166

Cooper, H. (2003). Editorial. Psychological Bulletin, 129, 3-9. doi: 10.1037/0033-2909.129.1.3

Danieli, Y. (1982). Families of survivors and the Nazi Holocaust: Some short- and long-term effects. In C. D. Spielberger, I. G. Sarason, \& N. Milgram (Eds.), Stress and anxiety (Vol. 8, pp. 405-423). Washington, DC: Hemisphere.

Davidson, S. (1981). Clinical and psychotherapeutic experience with survivors and their families. Family Physician, 10, 313-321.

De Graaf, T. (1975). Pathological patterns of identification in families of survivors of the Holocaust. Israel Annals of Psychiatry, 13, 335-363.

de Quervain, D. J.-F., Kolassa, I.-T., Ertl, V., Onyut, P. L., Neuner, F., Elbert, T., \& Papassotiropoulos, A. (2007). A deletion variant of the $\alpha 2 \mathrm{~b}$-adrenoceptor is related to emotional memory in Europeans and Africans. Nature Neuroscience, 10, 1137-1139. doi:10.1038/nn1945

Derogatis, L. R. (1977). SCL-90 administration, scoring and procedure manual. Baltimore, MD: Johns Hopkins University Press.

*de Vries, B., Suedfeld, P., Krell, R., Blando, J. A., \& Southard, P. (2005). The Holocaust as a context for telling life stories. International Journal of Aging and Human Development, 60, 213-228. doi:10.2190/TFHAD5K5-KQKK-8DE4

Dohrenwend, B. P., Shrout, P. E., Egri, G., \& Mendelsohn, F. S. (1980). Nonspecific psychological distress and other dimensions of psychopathology. Archives of General Psychiatry, 37, 1229-1236.

*Eaton, W. W., Sigal, J. J., \& Weinfeld, M. (1982). Impairment in Holocaust survivors after 33 years: Data from an unbiased community sample. American Journal of Psychiatry, 139, 773-777.

Eitinger, L. (1964). Concentration camp survivors in Norway and Israel. London, England: Allen \& Unwin.

Eitinger, L., \& Major, E. F. (1993). Stress of the Holocaust. In L. Goldberger \& S. Breznitz (Eds.), Handbook of stress: Theoretical and clinical aspects (2nd ed., pp. 617-640). New York, NY: Free Press.

Endler, N. S., Lobel, T. E., Parker, J. D. A., \& Schmitz, P. (1991). Multidimensionality of state and trait anxiety: A cross-cultural study comparing American, Canadian, Israeli and German young adults. Anxiety Research, 3, 252-272. doi:10.1080/08917779108248756

Erikson, E. H. (1959). Identity and the life cycle. New York, NY: International Universities Press.

*Fenig, S., \& Levav, I. (1991). Demoralization and social support among Holocaust survivors. Journal of Nervous and Mental Disease, 179, 167-172. doi:10.1097/00005053-199103000-00010

Ferren, P. M. (1999). Comparing perceived self-efficacy among adolescent Bosnian and Croatian refugees with and without posttraumatic stress disorder. Journal of Traumatic Stress, 12, 405-420.

Fink, K. (2003). Magnitude of trauma and personality change. International Journal of Psychoanalysis, 84, 985-995. doi:10.1516/350UFHQ2-RTDB-6HW8

Fitts, W. H. (1971). The self-concept and self-actualization (Monograph No. 3). Nashville, TN: Nashville Mental Health Center.

Fletcher, K. E. (1996). Childhood posttraumatic stress disorder. In E. J. Mash \& R. A. Barkley (Eds.), Child psychopathology (pp. 242-276). New York, NY: Guilford.

Folstein, M. F., Folstein, S. E., \& McHugh, P. R. (1975). "Mini-mental state": A practical method for grading the cognitive state of patients for the clinician. Journal of Psychiatry Research, 12, 189-198. doi: 10.1016/0022-3956(75)90026-6
Frankl, V. (1962). Man's search for meaning: An introduction to logotherapy. Boston, MA: Beacon.

Freedman, S., Gluck, N., Tuval-Mashiach, R., Brandes, D., Peri, T., \& Shalev, A. (2002). Gender differences in responses to traumatic events: A prospective study. Journal of Traumatic Stress, 15, 407-413. doi: 10.1023/A: 1020189425935

*Gay, M. (1982). The adjustment of parents of wartime bereavement. Series in Clinical and Community Psychology: Stress \& Anxiety, 8, 243-247.

Gibbons, F. X., Smith, T. W., Ingram, R. E., Pearce, K., Brehm, S. S., \& Schroeder, D. (1985). Self-awareness and self-confrontation: Effects of self-focused attention on members of a clinical population. Journal of Personality and Social Psychology, 48, 662-675. doi:10.1037/00223514.48.3.662

Gilbert, J. G., Levee, R. F., \& Catalano, F. L. (1968). A preliminary report on a new memory scale. Perceptual and Motor Skills, 27, 277-278.

Goldberg, J., True, W. R., Eisen, S., \& Henderson, W. G. (1990). A twin study of the effects of the Vietnam War on posttraumatic stress disorder. JAMA, 263, 1227-1232. doi:10/1001/jama.263.9/12270

*Golier, J. A., Yehuda, R., De Santi, S., Segal, S., Dolan, S., \& de Leon, M. J. (2005). Absence of hippocamal volume differences in survivors of the Nazi Holocaust with and without posttraumatic stress disorder Psychiatry Imaging: Neuroimaging, 139, 53-64.

*Goodman, C., Finkel, B., Naser, M., Andreyev, P., Segev, Y., Kurs, R.,... Bleich, A. (2007). Neurocognitive deterioration in elderly chronic schizophrenia patients with and without PTSD. Journal of Nervous and Mental Disease, 195, 415-420. doi:10.1097/ NMD.0b013e31802c1424

Gurland, B. J., Yorkstone, N. J., Stone, A. R., \& Frank, J. D. (1974). Structured and Scaled Interview to Assess Maladjustment. New York, NY: Springer.

*Hantman, S., \& Solomon, Z. (2007). Recurrent trauma: Holocaust survivors cope with aging and cancer. Social Psychiatry and Psychiatric Epidemiology, 42, 396-402. doi:10.1007/s00127-007-0177-0

Harel, Z. (1995). Serving Holocaust survivors and survivor families. Marriage and Family Review, 21, 29-50. doi:10.1300/J002v21n01_03

*Harel, Z., Kahana, B., \& Kahana, E. (1988). Psychological well-being among Holocaust survivors and immigrants in Israel. Journal of Traumatic Stress, 1, 413-429. doi:10.1007/BF00980364

Hedges, L. V. (1994). Fixed effects models. In H. Cooper \& L. V. Hedges (Eds.), The handbook of research synthesis (pp. 285-299). New York, NY: Russell Sage Foundation.

Hedges, L. V., \& Olkin, I. (1985). Statistical methods for meta-analysis. San Diego, CA: Academic Press.

Helmreich, W. (1992). Against all odds: Holocaust survivors and the successful lives they made in America. New York, NY: Simon \& Schuster.

Helweg-Larsen, P., Hoffmeyer, H., Kieler, F., Hess-Thaysen, E., HessThaysen, P., Thygesen, P., \& Hertel Wulff, M. H. (1952). Famine disease in German concentration camps. Acta Psychiatrica et Neurologica Scandinavica, 28(Suppl. 83), 1-460.

Horowitz, M. J., Wilner, N., \& Alvarez, W. (1979). Impact of Event Scale: A measure of subjective stress. Psychosomatic Medicine, 41, 209-218.

Hunter, J. E., \& Schmidt, F. L. (2000). Fixed effects versus random effects meta-analysis models: Implications for cumulative research knowledge. International Journal of Selection and Assessment, 8, 275-292. doi: 10.1111/1468-2389.00156

*Isaacowitz, D. M., Smith, T. B., \& Carstensen, L. L. (2003). Socioemotional selectivity and mental health among trauma survivors in old age. Aging International, 28, 181-199. doi:10.1007/s12126-003-1023-7

*Joffe, C., Brodaty, H., Luscombe, G., \& Ehrlich, F. (2003). The Sydney Holocaust study: Posttraumatic stress disorder and other psychological morbidity in an aged community sample. Journal of Traumatic Stress, 16, 39-47. doi:10.1023/A:1022059311147 
Kadushin, A. (1976). Adopting older children: Summary and implications. In A. M. Clarke \& A. D. B. Clarke (Eds.), Early experience: Myth and evidence (pp.). New York, NY: Free Press.

Kagan, J. (2007). A trio of concerns. Perspectives on Psychological Science, 2, 361-376.

Kagan, J., Snidman, N., Kahn, V., \& Towsley, S. (2007). The preservation of two infant temperaments into adolescence. Monographs of the Society for Research in Child Development, 72(Serial No. 287), vii-93. doi: 10.1111/j.1745-6916.2007.00049.x

Kahana, B., Harel, Z., \& Kahana, E. (1988). Predictors of psychological well-being among survivors of the Holocaust. In J. Wilson, Z. Harel, \& B. Kahana (Eds.), Human adaptation to extreme stress: From the Holocaust to Vietnam (pp. 171-192). New York, NY: Plenum Press.

*Kahana, B., Kahana, E., Harel, Z., Kelly, K., Monagham, P., \& Holland, L. (1997). A framework for understanding the chronic stress of Holocaust survivors. In B. H. Gottlieb (Ed.), Coping with chronic stress (pp. 315-342). New York, NY: Plenum Press.

*Kaminer, H., \& Lavie, P. (1991). Sleep and dreaming in Holocaust survivors: Dramatic decrease in dream recall in well-adjusted survivors. Journal of Nervous and Mental Disease, 179, 664-669.

*Kapeliuk, Y. (1995). Reminiscence functions, death anxiety, and the achievement of ego integrity among aging Holocaust survivors (Unpublished doctoral dissertation). Adelphi University.

Keilson, H. (1992). Sequential traumatization in children: A clinical and statistical follow-up study on the fate of the Jewish war orphans in the Netherlands. Jerusalem, Israel: Manges Press.

Kellermann, N. P. F. (2001). The long-term psychological effects and treatment of Holocaust trauma. Journal of Loss and Trauma, 6, 197218. doi:10.1080/108114401753201660

*Kohn Dor-Shav, N. (1978). On the long-range effects of concentration camp internment on Nazi victims: 25 years later. Journal of Consulting and Clinical Psychology, 46, 1-11.

Krell, R. (1993). Child survivors of the Holocaust: Strategies of adaptation. Canadian Journal of Psychiatry, 38, 384-389.

Krell, R., \& Sherman, M. I. (1997). Medical and psychological effects of concentration camps on Holocaust survivors. New Brunswick, NJ: Transaction.

Krystal, H. (1968). Studies of concentration camp survivors. In H. Krystal (Ed.), Massive psychic trauma (pp. 23-46). New York, NY: International Universities Press.

*Landau, R., \& Litwin, H. (2000). The effects of extreme early stress in very old age. Journal of Traumatic Stress, 13, 473-487. doi:10.1023/ A: 1007737425260

Lazarus, R. S., \& Folkman, S. (1984). Stress, appraisal, and coping. New York, NY: Springer.

Leon, G. R., Butcher, J. N., Kleinman, M., Goldberg, A., \& Almagor, M. (1981). Survivors of the Holocaust and their children: Current status and adjustment. Journal of Personality and Social Psychology, 41, 503-516. doi:10.1037/0022-3514.41.3.503

*Letzter-Pouw, S., \& Werner, P. (2003). The willingness to enter a nursing home: A comparison of Holocaust survivors with elderly people who did not experience the Holocaust. Journal of Gerontological Social Work, 40, 87-103. doi:10.1300/j083v40n04_07

Levav, I., \& Abramson, J. H. (1984). Emotional distress among concentration camp survivors: A community study in Jerusalem. Psychological Medicine, 14, 215-218. doi:10.1017/S003329170000324X

*Lev-Wiesel, R., \& Amir, M. (2003). Posttraumatic growth among Holocaust child survivors. Journal of Loss and Trauma, 8, 229-237. doi: 10.1080/15325020305884

Lipsey, M. W., \& Wilson, D. B. (2000). Practical meta-analysis. Thousand Oaks, CA: Sage.

Lomranz, J. (1995). Endurance and living: Long-term effects of the Holocaust. In S. E. Hobfoll \& M. W. de Vries (Eds.), Extreme stress and communities: Impact and intervention (pp. 325-352). Dordrecht, the Netherlands: Kluwer.

*Marcus, E. L., \& Menczel, J. (2007). Higher prevalence of osteoporosis among female Holocaust survivors. Osteoporosis International, 18, 1501-1506. doi:10.1007/s00198-007-0389-x

Mazor, A., Gampel, Y., Enright, R. D., \& Orenstein, R. (1990). Holocaust survivors: Coping with post-traumatic memories in childhood and 40 years later. Journal of Traumatic Stress, 3, 1-14. doi:10.1007/ BF00975132

Mullen, B. (1989). Advanced basic meta-analysis. Hillsdale, NJ: Erlbaum.

*Nadler, A., \& Ben-Shushan, D. (1989). Forty years later: Long-term consequences of massive traumatization as manifested by Holocaust survivors from the city and the kibbutz. Journal of Consulting and Clinical Psychology, 57, 287-293. doi:10.1037/0022-006X.57.2.287

*Nathan, T. S., Eitinger, L., \& Winnik, H. Z. (1964). A psychiatric study of survivors of the Nazi Holocaust: A study in hospitalized patients. Israel Annals of Psychiatry and Related Disciplines, 2, 47-76.

Nelson, C. A., Zeanah, C. H., Fox, N. A., Marshall, P. J., Smyke, A. T., \& Guthrie, D. (2007, December 21). Cognitive recovery in socially deprived young children: The Bucharest Early Intervention Project. Science, 318, 1937-1940. doi:10.1126/science.1143921

Niederland, W. G. (1968). The problem of the survivor: The psychiatric evaluations of emotional problems in survivors of Nazi persecution. In H. Krystal (Ed.), Massive psychic trauma (pp. 8-22). New York, NY: International University Press.

Paris, J. (2000). Predispositions, personality traits, and posttraumatic stress disorder. Harvard Review of Psychiatry, 8, 175-183. doi:10.1093/hrp/ 8.4.175

*Peretz, T., Baider, L., Ever-Hadani, P., \& Kaplan De-Nour, A. (1994). Psychological distress in female cancer patients with Holocaust experience. General Hospital Psychiatry, 16, 413-418. doi:10.1016/01638343(94)90117-1

Petticrew, M., \& Roberts, H. (2006). Systematic reviews in the social sciences: A practical guide. Oxford, England: Blackwell.

*Prager, E., \& Solomon, Z. (1995). Perceptions of world benevolence, meaningfulness and self-worth among elderly Israeli Holocaust survivors and non-survivors. Anxiety, Stress, and Coping, 8, 265-277. doi: $10.1080 / 10615809508249378$

*Robinson, S., Hemmendinger, J., Netanel, R., Rapaport, M., Zilberman, L., \& Gal, A. (1994). Retraumatization of Holocaust survivors during the Gulf war and SCUD missile attacks on Israel. British Journal of Medical Psychology, 67, 353-362.

Robinson, S., Rapaport, J., Durst, R., Rapaport, M., \& Rosca, P. (1990). Late effects of Nazi persecution among elderly Holocaust survivors. Acta Psychiatrica Scandinavica, 82, 311-315. doi:10.1111/j.16000447.1990.tb01391.x

*Rosen, J., Reynolds, C. F., Yeager, A. L., Houck, P. R., \& Hurwitz, L. F. (1991). Sleep disturbances in survivors of the Nazi Holocaust. Journal of Psychiatry, 148, 62-66.

Rosenthal, R. (1991). Meta-analytic procedures for social research (Rev. ed.) Beverly Hills, CA: Sage.

Rosenthal, R. (1995). Writing meta-analytic reviews. Psychological Bulletin, 118, 183-192. doi:10.1037/0033-2909.118.2.183

Rousseau, C., Drapeau, A., \& Rahimi, S. (2003). The complexity of trauma response: A 4-year follow-up of adolescent Cambodian refugees. Child Abuse and Neglect, 27, 1277-1290. doi:10.1016/j.chiabu.2003.07.001

Rutter, M. (1992). Psychological resilience and protective mechanisms. In J. Rolf, A. S. Masten, D. Cicchetti, K. H. Nuechterlein, \& S. Weintraub (Eds.), Risk and protective factors in the development of psychopathology (pp. 181-214). Cambridge, England: Cambridge University Press.

Sadavoy, J. (1997). Survivors: A review of the late-life effects of prior psychological trauma. American Journal of Geriatric Psychiatry, 5, 287-301. doi:10.1097/00019442-199700540-00004

*Sagi, A., Van IJzendoorn, M. H., Joels, T., \& Scharf, M. (2002). Disor- 
ganized reasoning in Holocaust survivors. American Journal of Orthopsychiatry, 72, 194-203. doi:10.1037/0002-9432.72.2.194

Sagi-Schwartz, A., Van IJzendoorn, M. H., \& Bakermans-Kranenburg, M. J. (2008). Does intergenerational transmission of trauma skip a generation? No meta-analytic evidence for tertiary traumatization with third generation of Holocaust survivors. Attachment and Human Development, 10, 1-17. doi:10.1080/14616730802113661

*Sagi-Schwartz, A., Van IJzendoorn, M. H., Grossman, K. E., Joels, T., Grossman, K., Scharf, M., ... Alkalay, S. (2003). Attachment and traumatic stress in female Holocaust child survivors and their daughters. American Journal of Psychiatry, 160, 1086-1092. doi:10.1179/ appi.ajp.160.6.1086

Schwartz, S., Dohrenwend, B. P., \& Levav, I. (1994). Nongenetic familial transmission of psychiatric disorders? Evidence from children of Holocaust survivors. Journal of Health and Social Behavior, 35, 385-402. doi: $10.2307 / 2137216$

Segev, T. (1992). The seventh million. Jerusalem, Israel: Keter.

*Shafir, A., Hirsch, M., \& Shepps, S. (1975). The delayed mental influence of the Holocaust experience as projected in a psychodiagnostic battery. Tel Aviv, Israel: Mental Health Clinic, Kupat Holim, and Tel Aviv University

*Shanan, J., \& Shahar, O. (1983). Cognitive and personality functioning of Jewish Holocaust survivors during the midlife transition (46-65) in Israel. Archiv fur Psychologie, 135, 275-294.

Shapira, A. (1998). The Holocaust: Private memories, public memory. Jewish Social Studies, 4, 40-58.

*Shmotkin, D., \& Lomranz, J. (1998). Subjective well-being among Holocaust survivors: An examination of overlooked differentiations. Journal of Personality and Social Psychology, 75, 141-155. doi:10.1037/ 0022-3514.75.1.141

Sigal, J. J. (1995). Long-term effects of the Holocaust: Empirical evidence for resilience in the first, second, and third generation. Psychoanalytic Review, 85, 579-585.

Sigal, J. J., \& Weinfeld, M. (1989). Trauma and rebirth: Intergenerational effects of the Holocaust. New York, NY: Praeger.

Sigal, J. J., \& Weinfeld, M. (2001). Do children cope better than adults with potentially traumatic stress? A 40-year follow-up of Holocaust survivors. Psychiatry, 64, 69-80. doi:10.1521/psyc.64.1.69.18236

*Soskolne, V., Kozohovitch, H., Deviri, H., \& Schreiber, S. (2005). Past history of prolonged traumatization and present health-related quality of life: Holocaust survivors before and after open-heart surgery. Stress and Health, 21, 61-72. doi:10.1002/smi.1040

Stanford, F. (1995). Aging stressors for Holocaust survivors and their families. Journal of Gerontological Social Work, 24, 131-153. doi: 10.1300/J083V24N01_10

*Suedfeld, P. (2003). Specific and general attributional patterns of Holocaust survivors. Canadian Journal of Behavioral Science, 35, 133-141.

*Suedfeld, P., Paterson, H., \& Krell, R. (2005). Holocaust survivors and the world of work. Journal of Genocide Research, 7, 243-254. doi: 10.1080/14623520500127522

Tabachnick, B. G., \& Fidell, L. S. (2001). Using multivariate statistics. New York, NY: Harper \& Row.

*Terno, P., Barak, Y., Hadjez, J., Wlizur, A., \& Szor, H. (1998). Holocaust survivors hospitalized for life: The Israeli experience. Comprehensive Psychiatry, 39, 364-367. doi:10.1016/S0010-440X(98)90049-9

*Trappler, B., Cohen, C. I., \& Tulloo, R. (2007). Impact of early lifetime trauma in later life: Depression among Holocaust survivors 60 years after liberation of Auschwitz. American Journal of Geriatric Psychiatry, 15, 79-83. doi:10.1097/01.JGP.0000229768.21406.a7

van der Hal-van Raalte, E. A. M., Van IJzendoorn, M. H., \& Bakermans-
Kranenburg, M. J. (2008). Sense of coherence moderates late effects of early childhood Holocaust exposure. Journal of Clinical Psychology, 64, 1-16. doi:10.1002/jclp.20528

Van IJzendoorn, M. H., Bakermans-Kranenburg, M. J., \& Sagi-Schwartz, A. (2003). Are children of Holocaust survivors less well-adapted? A meta-analytic investigation of secondary traumatization. Journal of Traumatic Stress, 16, 459-469. doi:10.1023/A:1025706427300

Van IJzendoorn, M. H., Juffer, F., \& Klein Poelhuis, C. W. (2005). IQ and school achievement of adopted children: A meta-analytic comparison with non-adopted children. Psychological Bulletin, 131, 301-316. doi: 10.1037/0033-2909.131.2.301

Waters, E. (1978). The reliability and stability of individual differences in infant-mother attachment. Child Development, 65, 1014-1027.

Wechsler, D. (1981). Wechsler Adult Intelligence Scale—Revised manual. San Antonio, TX: Psychological Corporation.

Werner, E. E. (2005). What can we learn about resilience from large-scale longitudinal studies? In S. Goldstein \& R. B. Brooks (Eds.), Handbook of resilience in children (pp. 91-105). New York, NY: Kluwer Academic/Plenum.

*Yaari, A., Eisenberg, E., Adler, R., \& Birkhan, J. (1999). Chronic pain in Holocaust survivors. Journal of Pain and Symptom Management, 17, 181-187. doi:10.1016/S0885-3924(98)00122-5

*Yehuda, R., Elkin, A., Binder-Brynes, K., Kahana, B., Southwick, S. M., Schmeidler, J., \& Giller, E. L. (1996). Dissociation in aging Holocaust survivors. American Journal of Psychiatry, 153, 940-953.

*Yehuda, R., Golier, J. A., Halligan, S. L., \& Harvey, P. D. (2004) Learning and memory in Holocaust survivors with posttrauamtic stress disorder. Biological Psychiatry, 55, 291-295. doi:10.1016/S0063223(03)00641-3

*Yehuda, R., Golier, J. A., Harvey, P. D., Stavitsky, K., Kaufman, S., Grossman, R. A., \& Tischler, L. (2005). Relationship between cortisol and age-related memory impairments in Holocaust survivors with PTSD. Psychoneuroendocrinology, 30, 678-687. doi:10.1016/j.psyneuen .2005.02.007

*Yehuda, R., Halligan, S. L., Grossman, R., Golier, J. A., \& Wong, C. (2002). The cortisol and glucocorticoid receptor response to low dose dexamethasone administration in aging combat veterans and Holocaust survivors with and without posttraumatic stress disorder. Biological Psychiatry, 52, 393-403. doi:10.1016/S006-3223(02)01357-4

*Yehuda, R., Kahana, B., Binder-Brynes, K., Southwick, S. M., Mason, J. W., \& Giller, E. L. (1995). Low urinary cortisol excretion in Holocaust survivors with posttraumatic stress disorder. American Journal of Psychiatry, 152, 982-986.

*Yehuda, R., Kahana, B., Schmeidler, J., Soutwick, S. M., Wilson, S., \& Giller, E. L. (1995). Impact of cumulative lifetime trauma and recent stress on current posttraumatic stress disorder symptoms in Holocaust survivors. American Journal of Psychiatry, 152, 1815-1818.

*Yehuda, R., Kahana, B., Southwick, S., \& Giller, E. L. (1994). Depressive features in Holocaust survivors with post-traumatic stress disorder. Journal of Traumatic Stress, 7, 699-704. doi:10.1007/BF02103016

Yehuda, R., Schmeidler, J., Siever, L. J., Binder-Brynes, K., \& Elkin, A (1997). Individual differences in posttraumatic stress disorder symptom profile in Holocaust survivors in concentration camps or in hiding. Journal of Traumatic Stress, 10, 453-463. doi:10.1023/A: 1024845422065

Received September 11, 2009

Revision received April 17, 2010 Accepted April 20, 2010 